\title{
Assessing the Averch-Johnson-Wellisz Effect for Regulated Utilities
}

\author{
Stephen M. Law ${ }^{1}$ \\ ${ }^{1}$ Economics Department, Mount Allison University, Sackville, New Brunswick, Canada \\ Correspondence: Stephen Law, Economics, Mount Allison University, Sackville, NB, E4L 1A7, Canada. Tel: \\ 1-506-364-2355. E-mail: slaw@mta.ca
}

Received: April 14, 2014

Accepted: May 5, 2014

Online Published: July 25, 2014

doi:10.5539/ijef.v6n8p41

URL: http://dx.doi.org/10.5539/ijef.v6n8p41

\begin{abstract}
This paper expands upon the observation of Paul Joskow (2005) that exploration of the Averch-Johnson-Wellisz (AJW) effect over the previous fifteen years had been a waste of time and effort. In a non-random selection of 192 articles published since 1962,39\% fail to specify or provide results of tests for necessary pre-conditions for the effect and in almost all remaining articles a strong conclusion should not be reached due to problems with single-period estimation, capital price calculations, definitions of output, or input complementarities. In general, there is little evidence to suggest that there was ever an AJW effect.
\end{abstract}

Keywords: industrial organization, inefficiency, regulation

\section{Introduction}

The purpose of this paper is to present the theoretical and empirical support for the Averch-Johnson-Wellisz (AJW) effect in network utilities under rate-of-return (ROR) regulation or, more accurately, to document the lack of evidence supporting the common claim that the AJW effect has had widespread and important impact on utilities. The primary AJW proposition states that if a regulated firm is required to choose an output price to earn no more than an allowed rate of return, based on the level of installed capital, this policy will create an incentive for the firm to choose a capital-labour ratio which is higher for the given output level than would be chosen without the regulation, that is, that ROR regulation causes distortions in input levels. This paper expands upon the notorious observation of Paul Joskow (2005) that exploration of the AJW effect over the previous fifteen years had been a waste of time and effort.

The propositions underlying the AJW effect have received considerable attention in the fifty years since the hypotheses were first published. Entering the title of the paper by Averch and Johnson into the search engine for JSTOR yields almost 9000 items. Using an idiosyncratic, non-random sample of 192 peer-reviewed journal articles published since Averch and Johnson (1962) and Wellisz (1963) proposed the effect, we find that almost $40 \%$ fail to specify or provide the results of tests for necessary pre-conditions before making assertions about the AJW effect or closely-related economic results of regulation. Further, close examination of the empirical results provided in remaining articles which claim to provide evidence of the AJW effect indicates that a strong conclusion as to the presence of the effect should not be reached due to (1) single- rather than multi-period estimation, (2) incorrect capital price calculations, (3) problematic definitions of output, or (4) the reason that for the firms in these regulated industries, installed capital assets are complementary to other inputs.

A necessary condition for the AJW effect is that capital and labour are to some significant extent substitutable in the production process. If they are complements the impact of the AJW effect is reduced or eliminated. If the two inputs are perfect complements then there is no scope for the AJW effect whatsoever. Another necessary condition is that the regulatory constraint is binding on the operations of the firm, which may not be the case if in the wider set of regulatory interactions that occur before and after the setting of the allowable rate of return there is some channel through which the firm can influence the outcome (Note 1). In addition, for the AJW effect to matter, the regulator must not have taken steps, by adjusting the time lag between regulatory hearings for example, to mitigate the effect (Note 2). Many theorists and empirical researchers believe that the AJW effect, even where it exists, is likely to be of very small impact (Note 3). An examination of the results of tests of complementarity and separation in the literature which reports empirical examinations of the production functions of regulated firms suggests that any network utility, which would have very high capital to labour ratios under any regulatory regime due to the nature of the associated production technology, might be generally 
characterised by complementarity (or a very low degree of substitution) of capital and labour. As a result, the kind of industry which is most often regulated is also the kind of industry in which we are least likely to see the AJW effect. Thus, while there may be other reasons to "not prefer" rate-of-return regulation, the AJW effect is not one of them.

Although the theoretical structure developed by Averch and Johnson (1962) and Wellisz (1963) has been carefully disseminated in courses in Industrial Organization and Regulatory Economics ever since its publication, the necessary empirical conditions for the AJW effect have often been ignored and typically remain untested in articles that nonetheless claim its pertinence (Note 4).

In 1973, almost eleven years-and many published studies-after the publication of the original 1962 article, Leland Johnson observed that: the question remains about the importance of overcapitalization and cross-subsidization in reality. Are the Averch-Johnson effects merely an intellectual curiosity, or do they describe serious distortions in the behavior of regulated firms? Unfortunately the answer is not clear. It is not enough to compare the behavior of regulated and unregulated firms (Note 5).

By 2005, Joskow's answer to Johnson's question appears to be that the AJW effects are an intellectual curiosity and this response is confirmed here.

One purpose of this paper is to document the prevalence of this failure to provide evidence to support an assertion of the importance of the AJW effect. Another is to connect observations about regulatory theory to this discussion. And, finally, this paper may provide the basis for a later assessment of Joskow's claim that wasted were the efforts over the past fifteen years to come to terms with the work of Averch, Johnson, and Wellisz. It is worthwhile to begin with the original statement of Averch and Johnson and follow its evolution over the subsequent decades.

\section{The Averch-Johnson-Wellisz Model and Interpretations}

\subsection{The AJ Model: Averch and Johnson (1962)}

In 1962, Harvey Averch and Leland Johnson published a paper in the American Economic Review which set out a model for a regulated monopolist producing an output, $z=z\left(x_{1}, x_{2}\right)$, inverse demand function given by $p=p(z)$, and two inputs, physical capital, $x_{1} \geq 0$, and labour, $x_{2} \geq 0$, such that $z\left(x_{1}, 0\right)=z\left(0, x_{2}\right)=0, \frac{\partial z}{\partial x_{1}}>0$ and $\frac{\partial z}{\partial x_{2}}>0$. With factor prices, $\mathrm{r}_{1}$ and $\mathrm{r}_{2}$, profit is given by $\pi=p z-r_{1} x_{1}-r_{2} x_{2}$. Given an acquisition cost for capital of $c_{1}$, current depreciation, $u_{1}$, and cumulative depreciation, $U_{1}$, the constraint for rate-of-return regulation can be written as

$$
s_{1} \geq \frac{p z-r_{2} x_{2}-u_{1}}{c_{1} x_{1}-U_{1}}
$$

where $s_{1}$ is the maximum allowable rate of return. Averch and Johnson set $U_{1}=u_{1}=0$ and $c_{1}=1$ for convenience and note that if $r_{1}>s_{1}$ the firm exits. Assuming $r_{1} \leq s_{1}$ they define

$$
L\left(x_{1}, x_{2}, \lambda\right)=p z-r_{1} x_{1}-r_{2} x_{2}-\lambda\left[p z-s_{1} x_{1}-r_{2}\right]
$$

and note that if $\lambda=0$, the firm is not constrained by the regulation, if $\lambda=1, r_{1}=s_{1}$, the firm is so constrained that any combination of $x_{1}$ and $x_{2}$ satisfying constraint (1) is a solution and, finally, if $0<\lambda<1$, then the firm is constrained by the regulation and "the input of $x_{1}$ is such that...its use is expanded beyond the point at which its marginal cost would be equal to its marginal value product" (Note 6).

Averch and Johnson note that "the extent to which the regulation affects output depends on the nature of the production function (and) if it involves fixed proportions, i.e., $\min \left(\frac{x_{1}}{a}, \frac{x_{2}}{b}\right)$, the regulated firm is constrained to the efficient expansion path" (Note 7).

\subsection{Geometric Interpretation: Zajac (1970)}

In 1970, Zajac published an article in the American Economic Review presenting a geometric interpretation of the AJW model. The motivation for the article, according to Zajac, was that "unfortunately, Averch and Johnson carried out their analysis using the rather abstract tools of nonlinear programming and the Kuhn-Tucker theorem (and hence) its detailed understanding has thereby been denied a large number of persons concerned with regulation for whom these tools are foreign and uncomfortable" (Note 8). Zajac recasts the regulatory constraint for a firm producing output, $q$, as:

$$
\frac{p q-w L}{K} \leq f
$$


where $x_{1}=K$ is capital with average factor cost of $r_{1}=i, x_{2}=L$ is labour with average factor cost of $r_{2}=w$ and $f$ is the "fair rate of return" imposed as a maximum by the regulator. Since profit is thus $\pi=p q-i K-w L$ the regulatory constraint is $\pi \leq(f-i) K$. Zajac then demonstrates that a profit-maximizing firm will choose the largest level of capital, $K_{\mathrm{MAX}}$, that satisfies the regulatory constraint. Over the following four decades, instructors of courses in Industrial Organization have laboured to reproduce the Zajac diagrams on blackboards, photocopied the figures for class hand-outs for their students, or required students to seek out Zajac's article on their own.

Zajac notes that a key assumption is that the rate of return set by the regulator exceeds the cost of capital (i.e., $f>$ i) but does not make any comment about the underlying technology of production. Zajac demonstrates that the firm does not have an incentive to acquire useless capital. An implication of this result is that if the underlying technology involves fixed proportions, the constraint curve depicted in Figures 2 and 3 will lie over the set of efficient points and the $K_{\mathrm{MAX}}$ point will be on the expansion path of efficient points, that is, there will be no Averch-Johnson effect. This result was noted by Averch and Johnson in their original article but, importantly, was omitted from Zajac's more accessible treatment of the AJW model. Importantly, because it was generally to Zajac (1970) that scholars and students of regulation turned when seeking "a detailed understanding" of the analysis of Averch and Johnson.

\subsection{Restatement and Correction: Baumol and Klevorick (1970)}

Another article which is essential for understanding the literature related to the AJW effect was also published in 1970. Baumol and Klevorick's article in the Bell Journal of Economics and Management Science begins by noting that the model in Averch and Johnson (1962) is similar to one published at almost the same time by Wellisz in the Journal of Political Economy (Note 9). Baumol and Klevorick suggest that "the phenomenon that emerges from the A-J theorem may not be of very great significance in practice" and "it is at least plausible that other potential sources of difficulty in the regulatory process dwarf the consequences of the distortion in the capital-labour ratio that the model predicts." Baumol and Klevorick restate the regulatory constraint as:

$$
s=r_{1}+v \geq \frac{p z-r_{2} x_{2}}{x_{1}}
$$

with $\mathrm{v} \geq 0$, assuming with Averch and Johnson, $U_{1}=u_{1}=0$ and $c_{1}=1$, and also making the standard assumption that " $r_{1}+v$ is taken to be less than the (unregulated) profit-maximizing rate of return" (Note 10). Baumol and Klevorick extend the logical structure created by Averch and Johnson and conclude that the original authors and those who took it up over the subsequent years (between 1962 and 1970) either implied or assumed the following propositions (Note 11):

Proposition 1: The profit-maximizing firm under regulatory constraint will tend to use a capital-labor ratio different than that which minimizes cost for its output level.

(Alleged) Proposition 2: The capital-labor ratio of the regulated firm will be larger than that of the unconstrained profit-maximizing monopolist.

Proposition 3: The capital-labor ratio of the regulated firm will be larger than the one that minimizes costs for the output level that it elects to produce.

(Alleged) Proposition 4: The regulated firm will produce an output larger than that which maximizes profits.

Proposition 5: For the firm that seeks to maximize total profit subject to the regulatory constraint, we have $\frac{\partial x_{1}}{\partial s}<0$ for $r_{l}<s<r_{m}$ (where $\mathrm{r}_{\mathrm{m}}$ is the rate of return obtained at the (unconstrained) profit-maximizing input-output combination). In other words, the greater the difference between $(s)$ the regulatory fair rate of return and $\left(r_{1}\right)$ the cost of capital (since we are increasing $s$ holding $r_{1}$ constant), the smaller will be the value of $x_{1}$, the firm's use of capital.

Proposition 6: The sales-maximizing firm under rate-of-return regulation is motivated to use a labor-capital ratio greater than that which minimizes cost for the output level it chooses to produce.

Baumol and Klevorick provide restatements of the proofs of Propositions 1 and 3. As might be supposed by the use of "alleged", they show that Propositions 2 and 4 are false. These points (1, "true"; 2, "false; 3, "true"; 4, "false") have been incorporated into standard regulatory theory and doubtless have provided the basis for a large number of exam questions in undergraduate courses in Industrial Organization or the Economics of Regulation.

In demonstrating Proposition 3, although it might appear at first that Baumol and Klevorick failed to consider the case of perfect complementarity between inputs, noting only that for the regulated firm " $z_{1} / z_{2}$, the marginal rate of substitution of capital for labor, is now below the ratio of input prices, $r_{1} / r_{2}$, (and) with diminishing marginal 
rate of substitution of capital for labor for a fixed output level, this can occur only as the result of relative increase in the use of capital" (Note 12).

Later in the paper, we find their statement that depending on the marginal rate of substitution between $x_{1}$ and $x_{2}$, the employment of labor may either increase or decrease as $s$ gets closer to $r_{1}$. If labor and capital are complementary in the gross revenue function, then as the quantity of capital used by the firm increases its use of labor will also rise. But if capital is a substitute for labor in producing revenue, then $x_{1}$ and $x_{2}$ will move in opposite directions in the A-J model (Note 13).

and that "since capital and labor can either be complements or substitutes in producing output....we simply cannot conclude that the A-J proposition 4 is always valid." (Note 14).

In their discussion of an article by Bailey and Coleman which develops a model of regulatory lag, Baumol and Klevorick connect the timing of regulatory reviews to the regulated firm's choice of capital level: "in practice, the rate-of-return constraint is not enforced continually" and "one might surmise that ... (regulatory lag) serves to weaken the A-J input-proportion effect, at least to some extent." (Note 15) This observation can be made more powerfully after considering the later contributions of Joskow, Spulber, Laffont, Tirole, and others who have sought to embed the regulatory constraint within a more general model of regulator-firm interactions (Note 16). We will return to this topic below. Nonetheless, in 1970, Baumol and Klevorick concluded that the conventional treatment of the effect of the regulatory constraint-without considering the regulatory lags or specifying more carefully the incentives of the firm-led to an overemphasis on the AJW effect as a source of inefficiency. They note that "the A-J overcapitalization is an example of the inefficiencies emphasized in the more conventional analyses. But even if it occurs in practice it does not seem likely to produce effects that are very serious." (Note 17). "The point is simply that while regulation may well be suspected of being the source of some non-negligible inefficiencies in the economy, it is not clear that the phenomenon encompassed by A-J analysis is the most disquieting of these." (Note 18). And further research has supported this point.

\subsection{Modern Restatements: Examples Church and Ware (2000), Caputo and Partovi (2002) and (2008)}

Caputo and Partovi (2002) provide a concise derivation of what Baumol and Klevorick labelled "Proposition 5" and show the equivalence of a number of different conditions, with economic content, that may be imposed to achieve this proposition. In so doing, they closed the debate between Akira Takayama and Mohamed El-Hodiri on the one hand (Note 19) and Israel Pressman and Arthur Carol on the other (Note 20) regarding the (theoretical) existence of the effect presented in Proposition 5. This effect, though, is not what is commonly taken to be the AJW effect. Researchers seeking an exhaustive and excellent derivation of the comparative statics of rate-of-return regulation should turn to the work of Caputo and Partovi (2008). This derivation includes consideration of most of the technical issues raised here, with the exception that risk aversion is not explicitly discussed.

For a fine summary of central issues related to the AJW model, interested readers are encouraged to turn to Church and Ware (2000) for their discussion of cost-of-service regulation (Note 21). Church and Ware present the AJW model and then go on to consider three mitigating factors: regulatory lag, prudence and facilities reviews, and regulatory risk. Under this last topic, they note that: the A-J model assumes that capital expenditures are not sunk. In fact utilities are regulated typically because they are natural monopolies due to large sunk capital investments (Note 22).

This point forms the basis for some of the observations provided below, drawn from empirical studies of regulated utilities.

\subsection{Theoretical Problems with the AJW Propositions}

The first problems with the Averch-Johnson-Wellisz model were in its construction. Many of these problems were corrected in subsequent reformulations such as Zajac (1970), Stonebender (1972) and Baumol and Klevorick (1970), who more carefully constructed the analysis, and even more recent papers such as Borrmann and Finsinger (2006) who calculate the range for the multiplier in the AJW model assuming that the profit function is single-peaked. Some authors maintained that the AJW proposition is fundamentally flawed, for example: it has been shown by L. Courville that a proof of overcapitalization requires the additional assumption of strictly convex isoquants....Thus, Courville has strengthened our contention "that the very assumptions used to prove the A-J effect. require an assumption that the A-J effect exists in the first place" (Note 23).

However, the requirement of strictly convex isoquants has not been found to be overly restrictive and, indeed, most researchers make this assumption, implicitly or explicitly.

A second problem with the AJW model was identified by Meyer (1979) who notes the importance of risk in 
investment decisions and observes that: even without the influence of rate of return regulation, a risk averse firm would not utilize least cost input/technology configurations ...implying a relative emphasis on variable inputs, not fixed inputs, as a way to buffer risk. Capital brings with it higher fixed costs which the risk averse firm shies away from. In an unconstrained setting...risk aversion biases input choice toward too little (capital) for least expected cost production, but under regulation the A-J term produces a countervailing balance toward least expected cost production rather than further away from it (Note 24).

To further underscore the importance of accounting for risk in understanding a regulated firm's valuation of capital, Meyer further observes that: "Since empirical data is drawn from actual situations involving uncertainty and varying degrees of risk aversion across regulated firms, the results may suggest at least one of the reasons definitive empirical results isolating an A-J effect have proved elusive when couched in an econometric methodology derived from a riskless framework." (Note 25).

A third set of problems to arise with the AJW model is even more serious and less amenable to correction by a more careful treatment of the risk-adjusted price of capital. The fundamental prediction of the model is that in the presence of rate-of-return regulation "given $Q, K / L$ is too high", that is, the capital-labour ratio, $K / L$, chosen by the firm will exceed the ratio that would be chosen by an unregulated firm, were that firm to be producing the same level of output, $Q$ (which it likely would not). But what if there is rate-of-return regulation and the most appropriate model of firm-regulator interaction predicts something else? Besanko and Spulber (1992) construct a model in which the firm chooses a level of capital and the regulator subsequently sets the price cap or allowed rate-of-return. Besanko and Spulber $(B \& S)$ predict that in the face of regulation, the firm chooses a lower than optimal level of cost-reducing capital because the regulator, acting second, would appropriate the returns from the capital (Note 26). We are left with the following problem: the AJW proposition states that if there is rate-of-return regulation, given $Q, K / L$ will be "too high"; while in contrast, the B\&S model suggests that if there is binding regulation, $K / L$ will be "too low", given $Q$. The primary distinction is whether the firm moves first or the regulator moves first. This distinction is easy to make in a theoretical model but much more difficult to test empirically. In practice, both the regulator and the firm continually emit signals about their intentions and their assessments of market and cost conditions. Regulatory hearings provide a formal forum for the dissemination of these signals and there are additional dissemination channels such as press releases, announcements, and interviews. Typically, firms can anticipate regulatory changes before they are passed by formal procedures and regulators follow developments in the industry at trade shows and through business reports and reports to shareholders.

Burness, Montgomery and Quirk (1980a and 1980b), BMQ hereafter, identify a competing hypothesis to the AJW model in Joskow (1974) based on the observation that rate reviews are typically initiated by the regulated firm rather than by the regulatory authority. They conclude that the Averch-Johnson model is not consistent with the observed facts that: "(1) regulatory agencies set prices as well as allowed rates of return; (2) regulated firms often operate in the inelastic portion of their demand curves; and (3) the impetus for regulatory review almost always comes from the regulated firm rather than the regulatory agency" (Note 27).

Nowell and Shogren (1991) extend this approach to analyze the timing of the request for a rate review, asserting that the evidence indicates that the regulatory agency does not blindly enforce the regulatory constraint. The timing of requests is a choice variable for the regulated firm and not the (regulatory) commission (Note 28).

The B\&S model and other similar models which set the regulator and the firm or firms inside a regulation game form a more general framework for the evaluation of regulation and, more importantly for this paper, for the construction of empirically-testable predictions about the behavior of firms. This wider set of possibilities does not rule out the AJW effect entirely since a richer model may deliver the AJW effect as a sub-case, one of many possible outcomes, but it reduces its general applicability (Note 29). For this wider model to be useful, we need a way of identifying the essential timing characteristic which would yield the AJW result versus the B\&S or other results. Assuming one can distinguish the temporal sequence of interactions one could test the following predictions, in the presence of ROR, if the regulator "moves first", for a given $Q$, there is a higher $K / L$; if the regulator "moves second", there is a lower $K / L$, given $Q$. More importantly, regardless of whether this temporal distinction can be made operational, while there may be reasons to suggest that regulators might want to steer clear of rate-of-return regulation, the automatic presumption that we get sub-optimal capital-labour ratios should be discarded.

In evaluating the AJW model as a theory of regulation, Laffont and Tirole (1993) state that: an oddity of the model is that the regulator, while actively enforcing the rate-of-return constraint, has no explicit objective function Furthermore, taking for granted that limiting the regulated firm's rent is a primary objective of the 
regulator it must be the that some unexplicit constraint prevents the regulator from extracting the firm's full rent. Could (the A-J model's regulatory) constraint emerge as the "reduced form" of a more complex model? If so, wouldn't the reduced form be sensitive to changes in the structural form, which would make comparative statics exercises perilous? (Note 30).

And subsequently, Joskow (2005) observes that: the Averch-Johnson model and its progeny have been replaced with a richer set of models of regulation, both normative and positive, that consider asymmetric information, political economy considerations, legal constraints on agency behavior and their effects on the incentive properties of regulatory mechanisms and ultimately on the behavior and performance of regulated firms. I have in mind here in particular work by Laffont and Tirole $(1986,1993)$ Baron and Besanko (1984), Lewis and Sappington (1988) and many others (Note 31).

Further, a final complication raised by theoretical analysis and most pertinent to empirical studies is that even if in a particular study of a regulated firm or firms there is some evidence of some distorted input choice resembling the AJW effect its source is not necessarily as posited by the AJW model (Note 32). We turn now to additional problems that arise when attempting to provide evidence of the AJW effect in empirical studies of regulated network utilities.

\section{The Averch-Johnson-Wellisz Model: Empirical Issues}

There is a fundamental problem in estimating parameters of cost or production functions of regulated firms. In the presence of regulation, a researcher may take published regulatory practices or posted rules and construct a regulatory constraint. The presence of the AJW effect is then assumed and the AJW model is used to obtain estimates of characteristics (such as input complementarity) of the regulated firm's technology. This method is used fairly commonly in the literature. An example of a theoretical presentation of this approach can be found in Färe and Logan (1983). Färe and Logan observe that if we can write down the regulatory constraint that gives rise to the AJW model we can use the specific prediction of the AJW model to back out the regulated firm's technology. They assume a particular response to the regulation and assume that the AJW effect is as predicted. Subsequent empirical use of this approach is based on the following binary test: either the regulation is binding and yields the AJW effect or it is not binding and there is no distortionary effect (Note 33). If the regulation is not binding then results assuming that it is and results ignoring the regulation should not be statistically different. If the results are statistically different, then most researchers conclude that the regulation is binding and has an impact as predicted by Averch, Johnson, and Wellisz. Among other problems, if the input distortion arises from some other source (e.g., cost pass-through rules) then the researcher may be left unable to perform the calculation required to back out the unregulated firm's technology. Further, as Färe and Logan themselves note, "to reconstruct the rate-of-return regulated production function, it is necessary to have knowledge about the rate-of-return constraint as well as to know the rate-of-return regulated cost function." (Note 34) So, unless the assumed regulatory constraint captures exactly the interaction between the firm and the regulator, when we use this approach, all conclusions are conditional on the accuracy of the formulation of the regulatory constraint. Given a sufficiently rich data set, we are able to examine past behaviour of regulated firms with the goal of determining the impact of regulation or uncovering features of the underlying technology. But there is a danger within these projects of assuming that which we have come to test (e.g., with a naïve application of the Färe and Logan methodology).

Beyond explanation, we may wish to forecast even if this exercise is complicated by the fact that our observations are coloured by the regulatory framework that is part of the specific data-generating process that a particular study might be investigating. If we wish to predict, we must have accounted for the effect of the regulatory game. Does the firm move first? Or does the regulator? Do their responses change over decades as economists publish papers suggesting that their responses are driven by expectations of changes to rates-of-return, capital-labour ratios, or other important economic variables? We must be sure our predictions are robust to the choice of game.

Previous papers have attempted identification through the use of (1) time-series (before-and-after comparison); (2) cross-section (comparison of regulated-and-not) plus combinations (panel data) and (3) less extreme versions of each of these, involving variation in the intensity of regulation. Examples of these approaches (from Joskow \& Rose, 1989) include Spann (1974) and Nelson and Wohar (1983).

But if identification is not so simple, if the data set employed does not deliver clean counter-factual scenarios for testing, then there is a problem with the assertion that rate-of return regulation has caused input distortion since the AJW model may not be responsible for the apparent result. There are many other possible explanations for "overcapitalization", some of them more readily identifiable, econometrically, than others (expectations held by 
the firm of rising demand, for example). The testing of the AJW effect occurred during a specific period of history, during which many large corporations in the private sector that were unregulated also operated with high capital-labor ratios or used excess labor. Part of the reason for these features of economic organization in this time included: the rising power of labor so that these measures would be adopted to avoid strikes or to avoid unionization; management practices of the time; measures to reduce labor turnover where workers had (unmeasured) human capital; and some part of an apparent excess use of capital inputs may be the implicit creation of an efficiency wage by reducing the effort-level of employees.

Joskow and Rose, commenting on the importance of identification when studying the impact of regulation, note that interactions of regulation with changing economic conditions may, when properly modeled, provide an additional way of identifying regulatory effects (Joskow, 1974; Carron \& MacAvoy, 1981; Hendricks, 1975; Burness, Montgomery, \& Quirk, 1980; Greene \& Smiley, 1984). In particular, certain regulatory constraints may be binding under one set of economic conditions, but not under another. Implementing this approach requires particular attention to the nature of the regulatory process under study and how it works when economic conditions change. Joskow's (1974) model of state public utility commission behavior provides an example of this approach (Note 35).

Note that "paying attention to the nature of the regulatory process" differs materially from "assuming the nature of the regulatory model" which is a less careful but more common approach. Joskow and Rose also claim that "estimates of firms' production functions, combined with information on input prices, can be used to test whether regulated firms make cost-minimizing output choices".

But from where are the production functions obtained? Typically-and problematically-from estimates based on the data drawn from the actual experience of the regulated firm or firms. Joskow and Rose go on to note that although: estimating demand functions for regulated firms should present no particular difficulties. We are not as sanguine about cost or production function estimation. Estimates of production or cost functions from observed combinations of outputs, inputs, input prices, and costs tend to rely on a number of implicit assumptions, including equilibrium conditions and exogenous factor prices. These may be implausible for many regulated markets (Note 36).

and, further to the extent that one treats factor prices as exogenous (when they are endogenous), or fails to model explicitly direct regulatory constraints on production decisions, the resulting cost estimates can be quite misleading (Note 37).

And what if the regulatory constraints are endogenous, the result of the game played by the firm and the regulator? Explicitly modelling regulatory constraints based on the publicly-released statements of the regulatory authority will not solve the empirical problem if the firms made input choices based on different constraints determined in a wider game. Further, assuming that the AJW constraints are necessarily binding, when estimating features of the underlying technology, is not a very viable approach if the underlying technology does not support the AJW model, if capital and labour are complements for example. We turn now to some of the empirical studies which grappled more or less carefully with these problems.

\section{Representations and Assessments of the Averch-Johnson-Wellisz Model}

"In my view, students of regulation of legal monopolies wasted at least 15 years extending the Averch-Johnson model of regulatory behaviour and trying to test it empirically without much success." (Note 38).

Entering the title of the paper by Averch and Johnson (1962) into the search engine for JSTOR yields 8922 items (as of December 2013). Once items which have no direct connection to the AJW model are removed by searching within those items for those with the authors' names, this number drops to 550. Finally, selecting from the remainder those articles which seem to pertain more-or-less directly to the issues raised here (and adding some relevant studies found through other searches) yields a non-random sample of 192 journal articles, book chapters, or working papers. This sample forms the basis for the analysis and comments of this section of the discussion (Note 39). It is intended to be at least somewhat representative of the response of economists to the AJW model. The sample itself is reproduced in the Appendix.

\subsection{The Problematic Studies: Inconclusive or Incomplete}

Following in the tradition of McKay (1976) who assesses three empirical investigations of the AJW effect-and extending evaluative principles to theoretical papers-the items in the sample are examined to determine what they contribute to the debate on the existence and importance of the AJW effect (Note 40). We consider four possible determinations of problem in decreasing order of importance: Type D ("problematic"), Type C ("not sufficiently careful"), Type B ("not sufficiently thorough") and Type A ("thorough"). (Note 41) Using the 
non-random sample of peer-reviewed articles, we calculate a number of evocative statistics.

The least serious category is the "not sufficiently thorough" grouping, which contains all papers which do not explicitly present all of the cases and required conditions for the AJW effect. A study is thorough if there is testing for necessary conditions of input substitution or separability or the papers presents explicit assumptions in model to address substitution and separability. Of the 192 items considered here, 163 or $84.9 \%$ fall into Group B or $\mathrm{C}$ or $\mathrm{D}$.

An unfortunately large number of studies-well over one third-are placed into the "not sufficiently careful" category. 74 items or $38.5 \%$ are articles of Type C or D. These papers are a subset of the "not thorough" set. Theoretical papers were placed into this category primarily for being misleading or incomplete, especially in regard to implicit assumptions (Note 42). The most common reason for a theoretical work to be considered "not careful" is if the substitutability of inputs was assumed without explicit mention of its importance. Empirical studies were placed in this category if the AJW effect is discussed (but not always asserted as "found") without a presentation of any tests for necessary pre-conditions, especially tests on the complementarity of inputs.

If we consider as "problematic" items which are flawed or incorrectly conclusive, 12 of the 192 or $6.25 \%$ fall into this category. These are the Type D articles, a subset of the "not careful" group. The primary reason for a paper to be placed in this category is for the AJW effect to be reported as "found" or "proven" either on the basis of an empirical study which is subsequently shown to suffer from methodological or data problems or for the AJW effect to be reported without any test for the presence of one or more of the economic conditions necessary for its existence (Note 43). These papers, then, go further than the "not careful" papers in that their authors claim to have provided evidence of the existence of the AJW effect, rather than simply discussing the AJW effect in passing. Given the apparent widespread acceptance of the AJW effect, the test for inclusion in this category is biased: no empirical paper which fails to find the AJW effect is labelled problematic. Readers should adjust their own posterior beliefs accordingly.

Another way for a paper to be considered "problematic" is if it presents one of the common misconceived versions of the AJW effect, that is, that the AJW propositions imply that the regulated firm will choose a capital stock that is too large, the regulated firm will pay a price for its capital that is too high, or that the regulated firm will acquire unproductive capital. None of these is correct.

Examples of problematic papers include Courville (1974), Spann (1974) and Petersen (1975) all of which are dealt with in McKay (1976) whose "single most important objection to these studies is that they neglect to take into account one of the basic assumptions which is made when production or cost functions are used to represent technological possibilities." Since regulatory authorities require utilities to satisfy demand, "the use of annual energy as the output and either total plant cost or capacity as the measure of capital contradicts....the assumption that engineering suboptimizations have taken place so that the function gives the maximum output attainable with the given inputs." (Note 44) Gollop and Karlson (1980) also provide evidence to refute the finding of the AJW effect in these three papers. They develop and apply a multiperiod econometric model....The resulting empirical description of the industry's technology and the estimated residential demand elasticity are consistent with the findings of other applied research. The important empirical conclusion, however, is that we find no evidence of input distortion (Note 45).

When Gollop and Karlson restrict their model to a single period, the result confirms the Averch-Johnson hypothesis and supports the earlier research by Spann (1974), Courville (1974), and Petersen (1975). The results of the more general inter- temporal model, however, suggest that the above inference is the result of specification bias and not regulatory bias. This contrasts with the single-period model inference that inefficient producer behavior can be attributed to rate-of- return regulation. This "inefficiency," however, most likely is due to specification bias, not regulatory bias. Three of the four estimating equations in the single period and multiperiod models are identical. Only the optimizing condition with respect to capital is specified differently. Of course, it is precisely this first-order condition that is central to the evaluation of the Averch-Johnson hypothesis (Note 46).

Another, more recent example of a Type D paper, is found in Saal and Parker (2001) who report finding an AJW effect in regulated water utilities in England and Wales. Capital for labor substitution has been occurring during the 1990s, something consistent with the argument that, where economic regulation allows for a rate of return on investment at or above the cost of capital, incentives exist to overinvest (Averch and Johnson 1962). Regulation of the water industry in the 1990s seems to have failed to counteract this tendency (Note 47).

But the study does not present any tests for necessary conditions; in particular, the substitutability of labour for capital in the operations of water and sewer services is simply assumed in the analysis (Note 48). 
We may conclude from this sample that economists in general have not been as careful as they might have been in discussing the hypotheses of the AJW model. Further, if we restrict our attention to empirical studies of regulated industries undertaken on unique data sets, 92 of the 192 papers in the sample, then they can be grouped as follows: $70.7 \%$ are not sufficiently thorough, $31.5 \%$ are not sufficiently careful and $4.4 \%$ are problematic.

\subsection{Evidence for the AJW Effect}

Some papers provide a careful counter-factual and do not assume the AJW effect before attempting to find it or discover its effect on the production or cost functions. Of the many papers that claim to have found evidence of the AJW effect, only a few use methodologies that are sufficiently thorough or careful. Even these studies, taken together, are not conclusive. For example, although Hayashi and Trapani (1976) find evidence of the AJW effect for US electric utilities during 1965-1969, Nelson and Wohar (1983) find no evidence of the AJW effect in US electric utilities for 1950-1973, but find evidence of the effect over the period 1974-1978.

Granderson and Lovell (1998) find the AJW effect in US Natural Gas Pipelines for 1977-1987 and, using much the same data set, Granderson and Linvil (1996) find evidence of the AJW effect for US Natural Gas Pipelines for 1981-1987 but not 1977-1980. The finding of the AJW effect is for the period just prior to the deregulation of this industry. It is possible that, at least toward the end of the sample period, as firms anticipated deregulation, more complex firm-regulator interactions were occurring than those contemplated by the AJW model.

Nemoto, Nakanishi and Madono (1993) find overcapitalization consistent with the AJW effect in nine Japanese electric utilities over the period 1981 to 1985 . The authors note that during this period "the government frequently encouraged investment of electric utilities as a complement to fiscal policy" and therefore "government intervention in the decision process of investment makes it unlikely that investment series in this period reflect rational behavior described by dynamic factor demand models." (Note 49) The results in the paper could also arise from a regulator's perceived need for security of supply in the event of a sudden large increase in demand.

A very persuasive finding of input bias in a regulated industry is provided by Atkinson, Färe and Primont (2002) for US Railroads, over the 1951-1975 period, but no claim that this input bias is the result of the AJW effect is advanced by the authors of this paper.

\subsection{Lack of Evidence of the AJW Effect}

One the reasons that researchers have not found much empirical support for the AJW effect may be that regulators who were aware of the effect would have taken action to prevent it through a mix of incentives and penalties applied to the regulated firms. Managers of regulated firms might be aware that regulators would respond to evidence for the AJW effect by imposing new regulations and seek to prevent the establishment of new rules. In this light, the study of Boyes (1976) is particularly interesting. Boyes examines a system of input demand functions for steam-electric generating plants in the Unites States (except Texas, South Dakota, Minnesota and Iowa) over the period 1957 to 1964 and finds no support for the AJW effect. The data set covers a period prior to publication of Averch-Johnson (1962) or Wellisz (1963) and so regulators are unlikely to have been influenced by the hypotheses of the AJW model.

Close examination of the empirical results provided in many empirical studies suggests that in many sectors the AJW effect could not be present since for the firms in these regulated industries, installed capital assets are complements to other inputs. While it is possible that there may be some substitution possibilities between capital and labour prior to the acquisition of the capital, after installation the two inputs are likely to be complements. Sankar (1977) observes that Dhrymes and Kurz (1964) found that, at the plant level, the partial elasticity of substitution between capital and labor is zero and that between capital and fuel is very small. Further, using time series data for the U.S. electric utility industry for the period 1949-1968, Sankar (1972) found that an investment function based on a Leontief-type production model performed better than the functions based on a neoclassical model. Perhaps, a more realistic model would be the one which permits greater substitution possibilities before the investment is undertaken and less substitution possibilities after the investment is made (Note 50).

And in Pescatrice and Trapani (1980) we find that an analysis of the objectives of the private firms in the sample reveals some evidence consistent with internal cost minimization as predicted by the (AJW) regulatory model. However, not all of the perverse (distortionary) behavior predicted by the static rate-of-return model can be confirmed. In particular, the positive relation between nonbase input prices and their quantities demanded was not observed in most cases. The fact that these input demand distortions do not manifest themselves in the data is most likely due to the fact that the comparison was performed for the generation of power only and that 
substitution possibilities among inputs is somewhat limited by technology in this facet of the operation (Note $51)$.

Finally, Nelson and Wohar (1987) in their study of US electric utilities note that It is...possible to obtain three different estimates of the elasticities of scale and substitution for the unregulated technology. The traditional estimates are appropriate for the assumption that regulation is not binding, while the Fare-Logan estimates are consistent with the assumptions of binding regulation and cost minimization with respect to capital (and, presumably, the assumption that the regulatory constraint is correctly specified). The estimates...from the variable cost function are appropriate in both of these cases and in the case when the firm is not in equilibrium with respect to its use of capital (Note 52).

It is worth observing that the estimate of the elasticity of substitution between capital and labour in this third specification-the variable cost function which is appropriate in all three cases-suggests that these two inputs are complements (Note 53).

The three examples presented here are all drawn from electric utilities but most regulated network industries share fundamental technological characteristics with electricity-especially the high sunk cost of capital that is required for the network itself-and that is why they are typically regulated. Thus the kind of industry which is most often regulated may also be the kind of industry in which we are least likely to see any significant AJW effect.

Consider telephone service, as another example. In commenting on the telecommunications industry Greenwald and Sharkey play down the need for concern over the AJW effect: Another potential distortion due to rate of return regulation is the distortion in investment decisions which may lead to overly capital intensive technologies. However, the size of the incentives involved is not clear, and the general empirical evidence supporting the existence of substantial economic inefficiencies of this sort is weak to non-existent (Note 54).

In a 1999 study of local telephone service in the United States, Resende finds that, although ROR is supposed to cause input bias in the regulated firm according to the AJW model, the removal of ROR does not cause any productivity gain from an end to the hypothesized input bias: The evidence indicates that alternative regulatory regimes (price-cap and incentive regulation) do not seem to play any role in improving productive efficiency, in comparison to traditional rate-of-return regulation. This result displays robustness with respect to the choice of the technical change variable (Note 55).

\subsection{Treatment of AJW Effect in Teaching Materials}

Given the wealth of evidence against the AJW hypothesis, how is this subject treated in the materials developed for teaching? To examine how past and current students might have been exposed to the AJW hypothesis, we can consider a sample of recent and current textbooks in Microeconomics and Industrial Organization.

Many textbooks for intermediate- or upper-level Microeconomic theory have kept this subject out of the content. Examples include: Besanko and Braeutigam (2005), Cowell (2005), Gravelle and Rees (2004), Jehle and Reny (2011), Perloff (2012), and Varian (2010). Pindyck and Rubinfeld (2013) discuss rate-of-return regulation as a topic but there is no mention of the AJW effect (Note 56). In contrast, Eaton, Eaton and Allen (2012) and Frank and Parker (2010) provide uncritical presentations of the Averch-Johnson effects which make no reference to the empirical literature which, in general, fails to support the hypothesis (Note 57). Instructors using these textbooks might consider providing some additional material to their students, such as a reading from one of the textbooks from the field of Industrial Organization where the topic is typically considered more systematically.

As expected, many textbooks, or collections of readings for courses, from the fields of Industrial Organization and Regulation Economics have more extensive treatments of rate-of-return regulation. At the graduate level, while the classic theory text In Industrial Organization, Tirole (1988), does not discuss the AJW effect, the classic Regulation text, Laffont and Tirole (1993) present the AJW model in the introductory chapter (Note 58). Brushing the results and extensions of the AJW model aside, along with "its much-discussed empirical relevance", Laffont and Tirole provide a concise critique of its structure, asking whether the regulatory constraint (similar to Equations (1), (3) or (4) above) could "emerge as the 'reduced form' of a more complex model. (and, if so), wouldn't the reduced form be sensitive to changes in the structural form, which would make comparative statics exercise perilous?" (Note 59) And more perilous would be an empirical estimation strategy that assumed the reduced form was binding over periods during which the structure of regulation was changing.

Also at the graduate level, Spulber (1989) provides an extensive development of the AJW model (Note 60). Spulber asserts that the static AJW model has serious limitations and "an empirical test for regulatory bias must involve specification of a dynamic model". (Note 61) As noted above, in their textbook for graduate and 
advanced undergraduate instruction, Church and Ware (2000) present the AJW hypothesis and discuss some of the important mitigating factors: regulatory lag, prudence and facilities reviews, and regulatory risk (Note 62).

In contrast, Viscusi, Harrington, Jr. and Vernon (2005), in a textbook for a similar level of instruction, present the Averch-Johnson effect with few qualifiers. They state that "Using what some today would regard as very strong assumptions about how regulation constrains the firm, it was shown that firms would choose too much capital relative to other inputs." (Note 63) They also note that although one might argue that the Averch-Johnson effect may provide an incentive for capital-intensive technological change, the net effect of rate-of-return regulation on innovation is not so clear.

At the undergraduate level, the treatment of the AJW effect is also mixed. Some texts dispense with the model altogether, such as the one from Pepall, Richards and Norman (2011) which does not contain any discussion of rate-of-return regulation. Some texts provide the necessary evidence or caveats. For example, Burgess (1995) states that "the question of whether or not the operations of regulated enterprise is subject to A-J effects is a matter of empirical testing (and on) this question the indications are mixed." (Note 64) Burgess also provides references to empirical tests of the AJW hypothesis: "Spann's (1974) study seemed to confirm it; Boyes' (1976) study did not." (Note 65) Another undergraduate-level textbook, from Waldman and Jensen, (2013) explains the AJW effect and provides a useful discussion of some of the related empirical literature, both supportive and not (Note 66).

Carlton and Perloff (2005) explain the AJ Effect and unfold a simple numerical example to show how the regulated firm responds to the regulation by overcapitalizing (Note 67). They include a note that "rate-of-return may lead to undercapitalization...because of dynamic considerations" (Note 68). The textbook also has a brief section dealing with some of the empirical evidence, citing the work of Courville (1974), Petersen (1975) and Spann (1974) in support, the technical criticism of McKay (1977), and the studies of Smithson (1978) and Baron and Taggart (1977) which do not support the hypothesis. Following this promising beginning, Carlton and Perloff nonetheless assert that "there is a general consensus that production under ROR is likely to be inefficient" despite their conclusion that "the empirical evidence on overcapitalization is mixed." (Note 69).

Some textbooks that present the model provide insufficient discussion of the empirical literature. Lipczynski and Wilson (2001) offer up the AJ effect as one of three problems with rate-of-return regulation, focussing only on the importance of the regulator's choice of constraint, noting that "if the rate of return is set at a wrong level it can encourage firms to either over- or underinvest in assets". (Note 70) In marked contrast to the assertions in this article, Sherman (2008) claims that "empirical tests ... have indicated a bias toward capital inputs and the finding of a bias is strong evidence that rate-of-return regulation reduces input efficiency." (Note 71).

In general, advanced-undergraduate / graduate level texts-such as Laffont and Tirole (1993), Church and Ware (2000), Spulber (1989)-deal with the AJW effect with considerable skepticism and with the caveats and discussion of empirical results required for readers to come to draw reasonably well-informed conclusions about the hypotheses of Averch and Johnson (1962) and Wellisz (1963). Of the remaining textbooks which present the AJW hypotheses, mostly textbooks at the undergraduate level, the majority do not successfully discuss the model along with the weakness of empirical support for the predictions of the model, with the result that students might have some difficulty in properly assessing the extent to which the effect has been found in outcomes of real ROR situations.

\section{Conclusions}

In most of the articles claiming to provide evidence of the AJW effect a strong conclusion should not have been reached due to (1) single- rather than multi-period estimation, (2) incorrectly specified capital prices, (3) problematic definitions of output, or (4) the reason that for the firms in these regulated industries, installed capital assets are complements to other inputs. Network industries, which typically have very high capital to labour ratios under any regulatory regime, are frequently characterised by complementarity of capital and labour. The kind of industry which is most often regulated under ROR may also be the kind of industry in which we are least likely to see the AJW effect.

A few studies have carefully found evidence suggestive of the AJW effect. Studies from the same period in different industries found no evidence and more recent papers have found no evidence of the AJW effect. Either there never was a very significant AJW effect and/or regulators read the economics literature, too, and took steps to mitigate the AJW effect.

Certainly, there is no justification for assuming the AJW effect in trying to reconstruct or estimate the unregulated cost or production function. Most currently-regulated industries have been regulated for some time 
and technological change occurred in the regulated context. On the one hand, some regulatory constraints that appear to be binding are not; on the other, effects of regulation can persist even after the regulatory constraint has been relaxed (Note 72). If we assume that we can specify the regulatory constraint, assume it binds, and then proceed with estimation then we must accept that our estimation results are conditional on the accuracy of our specification of the regulatory constraint. There are two prescriptions that arise from this paper:

(1) For empirical research: Consider the AJW effect, if at all, as one only possible outcome among many in the context of a set of regulatory interactions. Do not assume that the AJW effect is binding without careful testing.

(2) For pedagogy: Reduce the emphasis of the AJW effect in the teaching of Industrial Organization and present it, if at all, as one only possible outcome among many in the context of a set of regulatory interactions, along with possible mitigating factors.

It is not that the search for the AJW effect has not produced some interesting papers, just that this search could be abandoned in favour of more productive enterprises. Explorers who set out to find the Northwest Passage made other interesting discoveries. "Research" into the nature of philogiston, the ether, and the philosopher's stone yielded insights into chemistry, so too the exploration of the AJW effect has produced some important results for regulation economists (although not the secret of the transformation of lead into gold and perhaps not immortality). We can agree with Joskow (2005) that it is time to set aside further exploration which takes as its primary objective the identification of the size of the AJW effect but not that the research was "a waste of time and effort".

\section{Acknowledgments}

Law acknowledges support for this project from the Mount Allison University Research Fund. Research assistance for this project was provided by Adam Arsenault, David Byrne, Pippa Gherson, Nathan Hall, Marc Lalonde, Nelson Paterson, Jeff Spencer, and Advait Vij.

\section{References}

Atkinson, S. E., Rolf, F., \& Daniel, P. (2003). Stochastic Estimation of Firm Inefficiency Using Distance Functions. Southern Economic Journal, 69(3), 596-611. http://dx.doi.org/10.2307/1061696

Averch, H., \& Leland, L. J. (1962). Behavior of the Firm under Regulatory Constraint. American Economic Review, 52(5), 1052-1069.

Baron, D. P., \& David, B. (1984). Regulation, Asymmetric Information, and Auditing. RAND Journal of Economics, 15(4), 447-470. http://dx.doi.org/10.2307/2555518

Baumol, W. J., \& Alvin, K. K. (1970). Input Choices and Rate-of-Return Regulation: An Overview of the Discussion. Bell Journal of Economics and Management Science, 1(2), 162-190. http://dx.doi.org/10.2307/3003179

Berg, S. V., \& John, T. (1995). Contributions of Neoclassical Economics to Public Utility Analysis. Land Economics, 71(3), 310-330. http://dx.doi.org/10.2307/3146349

Besanko, D., \& Ronald, R. B. (2005) Microeconomics (2nd ed.). Danvers, Massachusetts: John Wiley \& Sons, Inc.

Besanko, D., \& Daniel, S. (1992). Sequential-Equilibrium Investment by Regulated Firms. RAND Journal of Economics, 23(2), 153-170. http://dx.doi.org/10.2307/2555981

Borrmann, J., \& Jörg, F. (2006). An Alternative Way of Determining the Range of Averch and Johnson's Lagrange Multiplier: A Note. Applied Economics Letters, 13(5), 269-271. http://dx.doi.org/10.1080/13504850500393907

Boyes, W. J. (1976). An Empirical Investigation of the Averch-Johnson Effect. Economic Inquiry, 14(1), 25-35. http://dx.doi.org/10.1111/j.1465-7295.1976.tb00374.x

Burgess, G. H. Jr. (1995). The Economics of Regulation and Antitrust. New York, NY: Harper Collins College Publishers.

Burness, H., Stuart, W., David, M., \& James, P. Q. (1980a). Capital Contracting and the Regulated Firm. American Economic Review, 70(3), 342-354.

Burness, H., Stuart, W., David, M., \& James, P. Q. (1980b). The Turnkey Era in Nuclear Power. Land Economics, 56(2), 188-202.

Caillaud, B. J. M., Roger, G., Patrick, R., \& Jean, T. (1988). Government Intervention in Production and 
Incentives Theory: A Review of Recent Contributions. RAND Journal of Economics, 19(1), 1-26. http://dx.doi.org/10.2307/2555394

Callen, J. L. (1978). Production, Efficiency, and Welfare in the Natural Gas Transmission Industry. American Economic Review, 68(3), 311-323.

Caputo, M. R., \& Hossein, P. M. (2002). Reexamination of the A-J Effect. Economics Bulletin, 12(8), 1-9.

Caputo, M. R., \& Hossein, P. M. (2008). Intrinsic Comparative Statics of a General Class of Profit-Maximizing Rate-of-Return Regulated Firms. Oxford Economic Papers, 60(2), 369-382. http://dx.doi.org/10.1093/oep/gpm037

Carlton, D. W., \& Jeffrey, M. P. (2005). Modern Industrial Organization (4th ed.). New York, NY: Pearson Addison Wesley.

Church, J., \& Roger, W. (2000). Industrial Organization: A Strategic Approach. Toronto: The McGraw-Hill Companies, Inc. Retrieved from http://homepages.ucalgary.ca/ jrchurch/page4/page4.html

Corey, G. R. (1971). The Averch and Johnson Proposition: A Critical Analysis. Bell Journal of Economics and Management Science, 2(1), 358-373. http://dx.doi.org/10.2307/3003173

Courville, L. (1974). Regulation and Efficiency in the Electric Utility Industry. Bell Journal of Economics and Management Science, 5(1), 53-74. http://dx.doi.org/10.2307/3003092

Cowell, F. A. (2005). Microeconomics: Principles and Analysis. Oxford, UK: Oxford University Press.

Crew, M. A. (1982). Efficiency and Regulation: A Basis for Reform. Managerial and Decision Economics, 3(4), 177-187. http://dx.doi.org/10.1002/mde.4090030403

Dhrymes, P. J., \& Mordecai, K. (1964). Technology and Scale in Electricity Generation. Econometrica, 32(3), 287-315. http://dx.doi.org/10.2307/1913038

Eaton, B., Curtis, D., Eaton, F., \& Douglas, W. A. (2012). Microeconomics: Theory with Applications (8th ed.). Toronto: Pearson Prentice Hall.

El-Hodiri, M., \& Akira, T. (1973). Behavior of the Firm under Regulatory Constraint: Clarifications. American Economic Review, 63(1), 235-237.

Evans, L., \& Steven, G. (1988). Public-Utility Regulators Are Only Human: A Positive Theory of Rational Constraints. American Economic Review, 78(3), 444-462.

Färe, R., \& James, L. (1983). The Rate-of-Return Regulated Firm: Cost and Production Duality. Bell Journal of Economics, 14(2), 405-414. http://dx.doi.org/10.2307/3003642

Färe, R., \& James, L. (1986). Regulation, Scale and Productivity: A Comment. International Economic Review, 27(3), 777-781. http://dx.doi.org/10.2307/2526694

Filer, J. E., \& Daniel, R. H. (1983). Empirical Tests for the Effect of Regulation on Firm and Interruptible Gas Service. Southern Economic Journal, 50(1), 195-205. http://dx.doi.org/10.2307/1058050

Frank, R. H., \& Ian, C. P. (2010). Microeconomics and Behaviour (4th ed.). Toronto: McGraw-Hill Ryerson.

Gal-Or, E., \& Michael, H. S. (1992). Regulatory Regimes in the Electric Power Industry: Implications for Capacity. Journal of Regulatory Economics, 4(3), 263-278. http://dx.doi.org/10.1007/BF00133623

Gollop, F. M., \& Stephen, R. K. (1980). The Electric Power Industry: An Econometric Model of Intertemporal Behavior. Land Economics, 56(3), 299-314. http://dx.doi.org/10.2307/3146033

Granderson, G., \& Carl, L. (1996). The Impact of Regulation on Productivity Growth: An Application to the Transmission Sector of the Interstate Natural Gas Industry. Journal of Regulatory Economics, 10(3), 291306. http://dx.doi.org/10.1007/BF00157674

Granderson, G., \& Knox, L. C. A. (1998). The Impact of Regulation on Input Substitution and Operating Cost. Southern Economic Journal, 65(1), 83-97. http://dx.doi.org/10.2307/1061353

Gravelle, H., \& Ray, R. (2004). Microeconomics (3rd ed.). Harlow, Essex, UK: Pearson Education Limited.

Greenwald, B. C., \& William, W. S. (1989). The Economics of Deregulation of Local Exchange Telecommunications. Journal of Regulatory Economics, 1(4), 319-339. http://dx.doi.org/10.1007/BF00139900

Hayashi, P. M., \& John, M. T. (1976). Rate of Return Regulation and the Regulated Firm's Choice of 
Capital-Labor Ratio: Further Empirical Evidence on the Averch-Johnson Model. Southern Economic Journal, 42(3), 384-398. http://dx.doi.org/10.2307/1056617

Jehle, G., \& Philip, J. R. (2011). Advanced Microeconomic Theory (3rd ed.). Harlow, UK: Pearson Education Limited.

Johnson, L. L. (1973). Behavior of the Firm under Regulatory Constraint: A Reassessment. American Economic Review, 63(2), 90-97.

Joskow, P. L. (1974). Inflation and Environmental Concern: Structural Change in the Process of Public utility Price Regulation. Journal of Law and Economics, 17(2), 291-327. http://dx.doi.org/10.1086/466794

Joskow, P. L. (2005). Regulation and Deregulation after 25 Years: Lessons Learned for Research in Industrial Organization. Review of Industrial Organization, 26(2), 169-193. http://dx.doi.org/10.1007/s11151-004-7295-6

Joskow, P. L., \& Nancy, L. R. (1989). The Effects of Economic Regulation. In R. Schmalensee \& R. D. Willig (Eds.), Handbook of Industrial Organization (Vol. II). Amsterdam, The Netherlands: Elsevier Science Publishers B.V.

Kolpin, V. (2001). Regulation and Cost Inefficiency. Review of Industrial Organization, 18(2), 175-182. http://dx.doi.org/10.1023/a:1007823231402

Laffont, J. J., \& Jean, T. (1986). Using Cost Observations to Regulate Firms. Journal of Political Economy, 94(3), 614-641. http://dx.doi.org/10.1086/261392

Laffont, J. J., \& Jean, T. (1993). A Theory of Incentives in Procurement and Regulation. Cambridge, Massachusetts: MIT Press.

Law, S. M. (1999). Holding the Line: The CRTC and the Pricing of Basic Canadian Cable Television Services. Canadian Journal of Economics, 32(2), 294-317. http://dx.doi.org/10.2307/136441

Law, S. M., \& James, F. N. (2003). Unintended and Persistent Consequences of Regulation: The Case of Cable Television in Canada. Journal of Network Industries, Competition and Regulation, 4(4), 389-408.

Lewis, T. R., \& David, E. M. S. (1988). Regulating a Monopolist with Unknown Demand. American Economic Review, 78(5), 986-998.

Lipczynski, J., \& John, W. (2001). Industrial Organization: An Analysis of Competitive Markets. Harlow, UK: Pearson Education, Ltd.

Liston, C. (1993). Price-Cap Versus Rate of Return Regulation. Journal of Regulatory Economics, 5(1), 25-48. http://dx.doi.org/10.1007/BF01066312

McKay, D. J. (1976). Has the Averch-Johnson Effect Been Empirically Verified? Social Sciences Working Paper 132, Division of the Humanities and Social Sciences, California Institute of Technology, October 1976.

Meyer, R. A. (1979). Regulated Monopoly under Uncertainty. Southern Economic Journal, 45(4), 1121-1129. http://dx.doi.org/10.2307/1056958

Needy, C. W. (1976). Social Cost of the A-J-W Output Distortion. Southern Economic Journal, 42(3), 486-489. http://dx.doi.org/10.2307/1056629

Nelson, R. A., \& Mark, E. W. (1983). Regulation, Scale Economies, and Productivity in Steam-Electric Generation. International Economic Review, 24(1), 57-79. http://dx.doi.org/10.2307/2526115

Nelson, R. A., \& Mark, E. W. (1987). A Reply to Regulation, Scale and Productivity: A Comment. International Economic Review, 28(2), 535-539. http://dx.doi.org/10.2307/2526742

Nemoto, J., Yasuo, N., \& Seishi, M. (1993). Scale Economies and Over-Capitalization in Japanese Electric Utilities. International Economic Review, 34(2), 431-440. http://dx.doi.org/10.2307/2526923

Nowell, C., \& Jason, F. S. (1991). The Timing of a Rate Request by a Regulated Firm. Southern Economic Journal, 57(4), 1054-1060. http://dx.doi.org/10.2307/1060333

Pepall, L., Daniel, J. R., \& George, N. (2011). Contemporary Industrial Organization, A Quantitative Approach. Danvers, Massachusetts: John Wiley \& Sons, Inc.

Perloff, J. M. (2012). Microeconomics (6th ed.). Boston, Massachusetts: Pearson Education, Inc.

Pescatrice, D. R., \& John, M. T. III (1980). The Performance and Objectives of Public and Private Utilities Operating in the United States. Journal of Public Economics, 13(2), 259-276. 
http://dx.doi.org/10.1016/0047-2727(80)90016-X

Petersen, H. C. (1975). An Empirical Test of Regulatory Effects. Bell Journal of Economics, 6(1), 111-126. http://dx.doi.org/10.2307/3003217

Pindyck, R. S., \& Daniel, L. R. (2013). Microeconomics (8th ed.). New York: Pearson Education, Inc.

Pressman, I., \& Arthur, C. (1971). Behavior of the Firm under Regulatory Constraint: Note. American Economic Review, 61(1), 210-212.

Pressman, I., \& Arthur, C. (1973). Behavior of the Firm under Regulatory Constraint: Reply. American Economic Review, 63(1), 238.

Resende, M. (1999). Productivity Growth and Regulation in US Local Telephony. Information Economics and Policy, 11(1), 23-44. http://dx.doi.org/10.1016/S0167-6245(98)00020-1

Rothwell, G. S., \& Kelly, A. E. (1987). A Note on Allowed and Realized Rates of Return of the US Electric Utility Industry. Journal of Industrial Economics, 36(1), 105-110. http://dx.doi.org/10.2307/2098600

Saal, D. S., \& David, P. (2001). Productivity and Price Performance in the Privatized Water and Sewerage Companies of England and Wales. Journal of Regulatory Economics, 20(1), 61-90. http://dx.doi.org/10.1023/A:1011162214995

Sankar, U. (1972). Investment Behavior in the US Electric Utility Industry 1948-1968. Bell Journal of Economics and Management Science, 3(2), 645-664. http://dx.doi.org/10.2307/3003043

Sankar, U. (1977). Depreciation, Tax Policy and Firm Behavior under Regulatory Constraint. Southern Economic Journal, 44(1), 1-12. http://dx.doi.org/10.2307/1057294

Shepherd, W. G. (1966). Regulatory Constraints and Public Utility Investment. Land Economics, 42(3), 348-354. http://dx.doi.org/10.2307/3145351

Sherman, R. (2008). Market Regulation. New York, NY: Pearson Addison Wesley.

Smithson, C. W. (1978). The Degree of Regulation and the Monopoly Firm: Further Empirical Evidence. Southern Economic Journal, 44(3), 568-580. http://dx.doi.org/10.2307/1057211

Spann, R. M. (1974). Rate of Return Regulation and Efficiency in Production: An Empirical Test of the Averch-Johnson Thesis. Bell Journal of Economics and Management Science, 5(1), 38-52. http://dx.doi.org/10.2307/3003091

Spiegel, Y., \& Daniel, F. S. (1994). The Capital Structure of a Regulated Firm. RAND Journal of Economics, 25(3), 424-440. http://dx.doi.org/10.2307/2555770

Spulber, D. F. (1989). Regulation and Markets. Cambridge, Massachusetts: MIT Press.

Stonebraker, R. J. (1972). A Geometric Treatment of Averch-Johnson's Behavior of the Firm Model: Comment. American Economic Review, 62(1/2), 140-141.

Takayama, A. (1969). Behavior of the Firm under Regulatory Constraint. American Economic Review, 59(3), 255-260.

Tirole, J. (1988). The Theory of Industrial Organization. Cambridge, Massachusetts: MIT Press.

Varian, H. R. (2010). Intermediate Microeconomics, A Modern Approach (8th ed.). New York, NY: W.W. Norton \& Company.

Viscusi, W. K., Joseph, E., Harrington, Jr., \& John, M. V. (2005). Economics of Regulation and Antitrust (4th ed). Cambridge, Massachusetts: MIT Press.

Waldman, D. E., \& Elizabeth, J. J. (2013). Industrial Organization: Theory and Practice (4th ed). New York, NY: Pearson Addison Wesley.

Wellisz, S. H. (1963). Regulation of Natural Gas Pipeline Companies: An Economic Analysis. Journal of Political Economy, 71(1), 30-43. http://dx.doi.org/10.1086/258732

Westfield, F. M. (1965). Regulation and Conspiracy. American Economic Review, 55(3), 424-443.

Winston, C. (1993). Economic Deregulation: Days of Reckoning for Microeconomists. Journal of Economic Literature, 31(3), 1263-1289.

Zajac, E. E. (1970). A Geometric Treatment of Averch-Johnson's Behavior of the Firm Model. American Economic Review, 60(1), 117-125. 


\section{Notes}

Note 1 . These necessary conditions have also been noted by other commentators, for example by Kolpin (2001) in the Review of Industrial Organization:

If the monopolist perceives there is even an implicit policy in which past behaviour may influence future allowed returns, the AJ effect does not apply and one need not expect cost inefficiency to be observed. Another class of examples emerges when production and/or profits fail differentiability. For instance, it is easy to construct examples in which a firm endowed with Leontief production technology will continue to employ labor and capital in efficient proportions when exposed to rate-of-return regulation. More generally, any scenario in which the marginal productivity of .capital. varies discontinuously with the availability of those inputs necessary for their operation is subject to the failure of the AJ effect. Kolpin (2001), page 181.

Note 2. See Church \& Ware (2000), page 849.

Note 3. See, inter alia, Baumol \& Klevorick (1970).

Note 4. I am not immune to this accusation (mea culpa). Fifteen years ago, I published an article studying a particular regulated industry in which I referred to the article by Averch \& Johnson and noted that the regulator's rules were biased toward capital investment (the structure of the price cap reduced the possibility that cost-savings from new equipment would be eroded by corresponding rate decreases; the capital expenditures price mechanism directly rewarded investment with rate increases; and the rate increases permitted when the rate-of-return was below a benchmark provided an additional incentive for these regulated firms to hold a larger stock of assets). Despite presenting results from estimation over data that might have provided some indication of whether capital and labour were substitutes, the article is regrettably silent on this matter.

Note 5. Johnson (1973), page 91.

Note 6. Averch \& Johnson (1962), page 1056.

Note 7. Averch \& Johnson (1962), page 1057. Also Corey (1971), at page 364, contains a diagram and a discussion of the absence of the AJW effect when inputs are complements.

Note 8. Zajac (1970), page 117.

Note 9. Unlike the addition of .Boiteux. to .Ramsey-Boiteux.-in Caillaud, Guesnerie, Rey \& Tirole (1988) and in A Theory of Incentives and Procurement by Jean-Jacques Laffont and Jean Tirole (1993)-which has been largely successful, as measured by increased citations of the work of Boiteux, the observation of William Baumol and Alvin Klevorick does not seem to have convinced many subsequent authors to adopt as the name of the regulatory model they discuss the Averch-Johnson-Wellisz model or its main result the AJW effect. In the years immediately following the publication of the AJW papers, some scholars were careful to mention both-examples include Westfield (1965) and Shepherd (1966)-some authors were careful to cite both, even if the contribution of Wellisz was not noted explicitly in the text-examples include Takayama (1969) and Corey (1971)-but despite a few rare exceptions-such as Needy (1976), Filer \& Hollas (1983) and Evans \& Garber (1988)-references to Wellisz drop off sharply after 1971 even while research into the AJ effect continues. In notable contrast to this observation are only a few articles-such as one in the American Economic Review by Callen (1978) and another in Land Economics by Berg \& Tschirhart (1995)-which refer to the AJW model.

Note 10. Baumol \& Klevorick (1970), page 164, emphasis added.

Note 11. Baumol \& Klevorick (1970), pages 162, 165, 166, 168, 175, and 180.

Note 12. Baumol \& Klevorick (1970), pages 167-168.

Note 13. Baumol \& Klevorick (1970), page 177.

Note 14. Baumol \& Klevorick (1970), page 178.

Note 15. Baumol \& Klevorick (1970), page 182.

Note 16. See, e.g., Laffont \& Tirole (1993), page 34.

Note 17. Baumol and Klevorick (1970), page 188.

Note 18. Baumol and Klevorick (1970), page 189.

Note 19. Takayama (1969), El-Hodiri \& Takayama (1973).

Note 20. Pressman \& Carol (1971), Pressman \& Carol (1973).

Note 21. Church \& Ware (2000), pages 841-852. 
Note 22. Church \& Ware (2000), page 850.

Note 23. Quotation drawn by Pressman \& Carol from page 210 of Courville's Carnegie-Mellon PhD Dissertation. Pressman \& Carol (1973), page 238.

Note 24. Meyer (1979), pages 1125-1126.

Note 25. Meyer (1979), page 1124.

Note 26. See also Spiegel \& Spulber (1994).

Note 27. Burness, Montgomery \& Quirk (1980b), page 198.

Note 28. Nowell \& Shogren (1991), page 1059.

Note 29. Liston (1993) discusses some examples of regulatory games that yield the AJW effect as a subcase:

Besanko (1984) argues that in a symmetric information environment the A-J model is unsatisfactory because it implicitly assumes that the regulator acts myopically. However, if the firm has private information about its productivity parameter, he suggests that the input bias could arise endogenously as part of the optimal regulatory regime. He constructs an adverse selection model in which the regulator uses a graduated ROR. that decreases with the capital employed, as well as its power to monitor capital investments. Because less productive firms benefit more from increases in capital than more productive ones, the graduated ROR induces them to self-select. The resulting over-capitalization (i.e., the input bias) is viewed as an unavoidable, although welfare improving, consequence of lower information rents. (See also Baron's (1990, 1380-1381) presentation of Besanko's model.) Liston (1993), Note 13, page 41.

Note 30. Laffont \& Tirole (1993), page 34.

Note 31. Joskow (2005), page 188.

Note 32. One example is provided by Gal-Or and Spiro. .A conclusion of the study is that the existing regulatory regime, which has as its primary instrument the determination of allowed rate of return on invested capital, provides utilities with incentives to invest in base-load capacity at levels that exceed the socially optimal level. Although this conclusion is similar to that derived in the seminal paper by Averch and Johnson (1962)..., it is derived from a model which is substantially different from theirs. Furthermore, our conclusions are stronger.. Gal-Or \& Spiro (1992), page 264.

Note 33. This procedure sometimes involves estimating the Lagrangian multiplier (from Equation 2 above) and testing whether it is significantly different from zero or from one.

Note 34. Färe and Logan (1983), page 406.

Note 35. Joskow \& Rose (1989), page 1461.

Note 36. Joskow \& Rose (1989), page 1463.

Note 37. Joskow \& Rose (1989), page 1463.

Note 38. Joskow (2005), page 188.

Note 39. Some articles are excluded from our sample although they contain a reference to the AJW effect. These papers mention AJW in order to indicate that they are not studying ROR or AJW but instead studying, for example, debt-service regulations or accounting rules or other issues.

Note 40. Earlier reviews of the evidence for the AJW effect that have been published, such as MacKay (1976), Crew (1982) and Winston (1993), draw conclusions on the basis of smaller samples of published studies. For example, Crew (1982) suggests the following papers find support for the AJW effect-Courville (1974), Hayashi \& Trapani (1976), Peterson (1975) and Spann (1974)-and the following works do not find support-Boyes (1976), Crew \& Kleindorfer (1980 and 1982), and Smithson (1978).

Note 41 . The categorization of papers was performed by individuals with no personal ties to any of the authors, primarily student research assistants who were instructed to separate the papers without remorse or mercy. Nothing in the categories should be taken as a commentary on the competence of the authors since later developments can often render work problematic in hindsight.

Note 42. Caputo \& Partovi (2002) provide a precise, and convenient, set of statements for the economic conditions which may be assumed in order to establish the AJW model.

Note 43. Rothwell \& Eastman (1987) emphasize the importance of measuring the cost of capital carefully before drawing any conclusion about the AJW effect, noting that: 
Different measures of the cost of capital yield different conclusions about the appropriateness of using models assuming the same financial and regulatory constraints as in Averch and Johnson (1962). The realized rate of return was greater than the AFUDC rate for all years except 1981. However, when we use a market price of the cost of capital, the realized rate of return was less than the cost of capital from 1979 to 1982 . This finding violates the financial constraint of the single-period Averch-Johnson model, suggesting that the model is an inappropriate description of electric utility behavior in the late 1970s and early 1980s. (This does not imply that the model is necessarily appropriate before the late 1970s.) Also, we found that the allowed rate of return was greater than the realized rate after 1976. Using the realized rate as a proxy for the allowed rate in single-period models will bias estimates of overcapitalization toward accepting the Averch-Johnson thesis. Rothwell \& Eastman (1987) page 108.

Note 44. McKay (1976), page 2.

Note 45. Gollop \& Karlson (1980), page 313.

Note 46. Gollop \& Karlson (1980), page 313.

Note 47. Saal \& Parker (2001), page 87.

Note 48. Although many of the utilities in their sample reduce labor input and increase capital input while increasing output, the authors provide no elasticities or statistics to support a conclusion of substitution.

Note 49. Nemoto, Nakanishi \& Madono (1993), page 432.

Note 50. Sankar (1977) note 2, page 2.

Note 51. Pescatrice \& Trapani (1980), pages 274-275.

Note 52. Nelson \& Wohar (1987), page 538.

Note 53. Nelson \& Wohar (1987), Table 1, page 538.

Note 54. Greenwald \& Sharkey (1989), page 325.

Note 55. Resende (1999), page 41.

Note 56. Pindyck \& Rubinfeld (2013), pages 381-382.

Note 57. Eaton. Eaton \& Allen (2012), pages 357-361; Frank \& Parker (2010), pages 381-383.

Note 58. Laffont \& Tirole (1993), pages 33-34. In a section of the subsequent chapter, on pages 93-99, Laffont and Tirole further present a more thorough discussion of Private Information on the Desirability of Investment: Rate of Return on Investment, Incentives and the Averch-Johnson Model in which they ask (page 95): Is an Averch-Johnson overinvestment a concern in an optimal regulatory scheme? They contrast the behavior of the regulator and regulated firm under uncertainty about the cost of investment with the behavior of the firm in the AJW model, noting the inconsistency of the results of the AJW model and their more general theoretical model.

Note 59. Laffont \& Tirole (1993), page 34.

Note 60. Spulber (1989), pages 287-293.

Note 61. Spulber (1989), page 292.

Note 62. Church \& Ware (2000), pages 847-851.

Note 63. Viscusi, Harrington, Jr. \& Vernon (2005), page 433.

Note 64. Burgess (1995), page 71.

Note 65. Burgess (1995), Note 6, page 93.

Note 66. Waldman \& Jensen (2013), pages 633-635.

Note 67. Carlton \& Perloff (2005), pages 707-712.

Note 68. Carlton \& Perloff (2005), Note 30, page 709, emphasis added.

Note 69. Carlton \& Perloff (2005), page 712.

Note 70. Lipczynski \& Wilson (2001), page 392.

Note 71. Sherman (2008), page 422.

Note 72. See, e.g., Law \& Nolan (2003). 


\section{Appendix A}

\section{Citations for Articles in Dataset}

Papers published after 1989 (.in the last fifteen years. before Paul Joskow's 2005 paper in the Review of Industrial Organization) have a bold date of publication.

1) Adrangi, B., Garland, C., \& Kambiz, R. (1995). Analysis of the Deregulation of the US Trucking Industry: A Profit Function Approach. Journal of Transport Economics and Policy, 29(3), 233-246.

2) Alesina, A., Silvia, A., Giuseppe, N., \& Fabio, S. (2005). Regulation and Investment. Journal of the European Economic Association, 3(4), 791-825. http://dx.doi.org/10.1162/1542476054430834

3) Atikinson, A. B., \& Waverman, L. (1973). Resource Allocation and the Regulated Firm: Comment. Bell Journal of Economics and Management Science, 4(1), 283-287. http://dx.doi.org/10.2307/3003149

4) Atkinson, S. E., \& Christopher, C. (1994). Parametric Estimation of Technical and Allocative Inefficiency with Panel Data. International Economic Review, 35(1), 231-243. http://dx.doi.org/10.2307/2527099

5) Atkinson, S. E., \& Robert, H. (1976). Interfuel Substitution in Steam Electric Power Generation. Journal of Political Economy, 84(5), 959-978. http://dx.doi.org/10.1086/260492

6) Atkinson, S. E., \& Robert, H. (1980). A Test of Relative and Absolute Price Efficiency in Regulated Utilities. Review of Economics and Statistics, 62(1), 81-88. http://dx.doi.org/10.2307/1924275

7) Atkinson, S. E., \& Robert, H. (1984). Parametric Efficiency Tests, Economies of Scale, and Input Demand in U.S. Electric Power Generation. International Economic Review, 25(3), 647-662. http://dx.doi.org/10.2307/2526224

8) Atkinson, S. E., Rolf, F., \& Daniel, P. (2003). Stochastic Estimation of Firm Inefficiency Using Distance Functions. Southern Economic Journal, 69(3), 596-611. http://dx.doi.org/10.2307/1061696

9) Averch, H., \& Leland, L. J. (1962). Behavior of the Firm under Regulatory Constraint. American Economic Review, 52(5), 115-121.

10) Azariadis, C., Kalman, J. C., \& Alfredo, P. (1972). A Partial Utility Approach to the Theory of the Firm. Southern Economic Journal, 38(4), 485-494. http://dx.doi.org/10.2307/1056504

11) Bailey, E. E. (1972). Peak-Load Pricing under Regulatory Constraint. Journal of Political Economy, 80(4), 662-679. http://dx.doi.org/10.1086/259918

12) Bailey, E. E. (1973). Resource Allocation and the Regulated Firm: Comment on the Comments. Bell Journal of Economics and Management Science, 4(1), 288-292. http://dx.doi.org/10.2307/3003150

13) Bailey, E. E., \& Roger, D. C. (1971). The Effect of Lagged Regulation in an Averch-Johnson Model. Bell Journal of Economics and Management Science, 2(1), 278-292. http://dx.doi.org/10.2307/3003168

14) Bailey, E. E., \& Malone, J. C. (1970). Resource Allocation and the Regulated Firm. Bell Journal of Economics and Management Science, 1(1), 129-142. http://dx.doi.org/10.2307/3003026

15) Baron, D. P., \& Robert, A. T. Jr. (1977). A Model of Regulation under Uncertainty and a Test of Regulatory Bias. Bell Journal of Economics, 8(1), 151-167. http://dx.doi.org/10.2307/3003491

16) Barzel, Y. (1963). Productivity in the Electric Power Industry. Review of Economics and Statistics, 45(1), 395-408. http://dx.doi.org/10.2307/1927924

17) Barzel, Y. (1964). The Production Function and Technical Change in the Steam Power Industry. Journal of Political Economy, 72(2), 133-150. http://dx.doi.org/10.1086/258883

18) Baumol, W. J., \& Burton, G. M. (1967). The Firm's Optimal Debt-Equity Combination and The Cost of Capital. Quarterly Journal of Economics, 81(4), 547-578. http://dx.doi.org/10.2307/1885578

19) Baumol, W. J., Dietrich, F., \& Thijs, T. R. (1979). The Price-Iso Return Locus and Rational Rate Regulation. Bell Journal of Economics, 10(2), 648-658. http://dx.doi.org/10.2307/3003356

20) Baumol, W. J., \& Alvin, K. K. (1970). Input choices and Rate-of-Return Regulation: An Overview of the Discussion. Bell Journal of Economics and Management Science, 1(2), 162-190. http://dx.doi.org/10.2307/3003179

21) Bawa, V. S., \& David, S. S. (1980). Dynamic Behavior of a Firm Subject to Stochastic Regulatory Review. International Economic Review, 21(3), 627-642. http://dx.doi.org/10.2307/2526358 
22) Bhattacharyya, A., Elliott, P., \& Kambiz, R. (1994). An Examination of the Effect of Ownership on the Relative Efficiency of Public and Private Water Utilities. Land Economics, 70(2), 197-209. http://dx.doi.org/10.2307/3146322

23) Biglaiser, G., \& Michael, R. (2000). Dynamics of Price Regulation. RAND Journal of Economics, 31(4), 744-767. http://dx.doi.org/10.2307/2696357

24) Blair, R. D., David, L. K., \& Patricia, L. P. (1985). A Note on Purchased Power Adjustment Clauses. Journal of Business, 58(4), 409-417. http://dx.doi.org/10.1086/296306

25) Blitz, R. C., \& Millard, F. L. (1965). The Economics of Usury Regulation. Journal of Political Economy, 73(6), 608-619. http://dx.doi.org/10.1086/259087

26) Boyes, W. J. (1976). An Empirical Examination of the Averch-Johnson Effect. Economic Inquiry, 14(1), 25-35. http://dx.doi.org/10.1111/j.1465-7295.1976.tb00374.x

27) Braeutigam, R. R., \& John, C. P. (1989). Diversification Incentives under Price-Based and Cost-Based Regulation. RAND Journal of Economics, 20(3), 373-391.

28) Braeutigam, R. R., \& John, C. P. (1993). Effects of the Change from Rate-of-Return to Price-Cap Regulation. American Economic Review, 83(2), 191-198.

29) Brandon, P. S. (1971). The Electric Side of Combination Gas-Electric Utilities. Bell Journal of Economics and Management Science, 2(2), 688-703. http://dx.doi.org/10.2307/3003014

30) Brennan, M. J., \& Eduardo, S. S. (1982). Consistent Regulatory Policy under Uncertainty. Bell Journal of Economics, 13(2), 506-521. http://dx.doi.org/10.2307/3003470

31) Breslaw, J., \& Smith, J. B. (1982). The Restrictiveness of Flexible Functional Forms and the Measurement of Regulatory Constraint. Land Economics, 58(4), 553-558. http://dx.doi.org/10.2307/3145701

32) Brocas, I., Kitty, C., \& Isabelle, P. (2006). Regulation under Asymmetric Information in Water Utilities. American Economic Review, 96(2), 62-66.

33) Callen, J. L. (1978). Production, Efficiency, and Welfare in the Natural Gas Transmission Industry. American Economic Review, 68(3), 311-323.

34) Callen, J. L., Frank, M. G., \& Herbert, M. (1976). The Benefits and Costs of Rate of Return Regulation. American Economic Review, 66(3), 290-297.

35) Caputo, M. R., \& Hossein, P. M. (2002). Reexamination of the A-J Effect. Economics Bulletin, 12(8), 1-9.

36) Caputo, M. R., \& Hossein, P. M. (2008). Intrinsic Comparative Statics of a General Class of Profit-Maximizing Rate-of-Return Regulated Firms. Oxford Economic Papers, 60(2), 369-382. http://dx.doi.org/10.1093/oep/gpm037

37) Christensen, L. R., \& William, H. G. (1976). Economies of Scale in U.S. Electric Power Generation. Journal of Political Economy, 84(4), 655-676. http://dx.doi.org/10.1086/260470

38) Courville, L. (1974). Regulation and Efficiency in the Electric Utility Industry. Bell Journal of Economics and Management Science, 5(1), 53-74. http://dx.doi.org/10.2307/3003092

39) Cowing, T. G., \& Kerry, V. S. (1977). A Note on the Variability of the Replacement Investment Capital Stock Ratio. The Review of Economics and Statistics, 59(2), 238-243. http://dx.doi.org/10.2307/1928823

40) Crew, M. A., \& Paul, R. K. (1978). Reliability and Public Utility Pricing. American Economic Review, 68(1), 31-40.

41) Crew, M. A., \& Paul, R. K. (1979). Managerial Discretion and Public Utility Regulation. Southern Economic Journal, 45(3), 696-709. http://dx.doi.org/10.2307/1057470

42) Crew, M. A., \& Paul, R. K. (1983). Regulatory Influences on Managerial Incentives: Comment. Southern Economic Journal, 50(1), 265-266. http://dx.doi.org/10.2307/1058062

43) Das, S. P. (1980). On the Effect of Rate of Return Regulation under Uncertainty. American Economic Review, 70(3), 456-460.

44) Datta, A. (2003). Divestiture and Its Implications for Innovation and Productivity Growth in US Telecommunications. Southern Economic Journal, 69(3), 644-658. http://dx.doi.org/10.2307/1061699

45) Daughety, A. F. (1984). Regulation and Industrial Organization. Journal of Political Economy, 92(5), 932953. http://dx.doi.org/10.1086/261265 
46) Davis, E. G. (1973). A Dynamic Model of the Regulated Firm with a Price Adjustment Mechanism. Bell Journal of Economics and Management Science, 4(1), 270-282. http://dx.doi.org/10.2307/3003148

47) De Borger, B. L. (1984). Cost and Productivity in Regional Bus Transportation: The Belgian Case. Journal of Industrial Economics, 33(1), 37-54. http://dx.doi.org/10.2307/2098423

48) Dhrymes, P. J. (1964). On the Theory of the Monopolistic Multiproduct Firm under Uncertainty. International Economic Review, 5(3), 239-257. http://dx.doi.org/10.2307/2525510

49) Dhrymes, P. J., \& Mordecai, K. (1964). Technology and Scale in Electricity Generation. Econometrica, 32(3), 287-315. http://dx.doi.org/10.2307/1913038

50) Dodds, D. E., \& Jonathan, A. L. (1994). Can Utility Commissions Improve on Environmental Regulations? Land Economics, 70(1), 63-76. http://dx.doi.org/10.2307/3146441

51) Edelson, N. M. (1971). Resource Allocation and the Regulated Firm: A Reply to Bailey and Malone. Bell Journal of Economics and Management Science, 2(1), 374-378. http://dx.doi.org/10.2307/3003174

52) El-Hodiri, M., \& Akira, T. (1973). Behavior of the Firm under Regulatory Constraint: Clarifications. American Economic Review, 63(1), 235-237.

53) Elton, E. J., \& Martin, J. G. (1977). Optimal Investment and Financing Patterns for a Firm Subject to Regulation with a Lag. Journal of Finance, 32(5), 1485-1500. http://dx.doi.org/10.1111/j.1540-6261.1977.tb03349.x

54) Emmons, W. M. (1997). Implications of Ownership, Regulation, and Market Structure for Performance: Evidence from the US Electric Utility Industry before and after the New Deal. Review of Economics and Statistics, 79(2), 279-289. http://dx.doi.org/10.1162/003465397556638

55) Evans, L., \& Steven, G. (1988). Public-Utility Regulators Are Only Human: A Positive Theory of Rational Constraints. American Economic Review, 78(3), 444-462.

56) Farber, S. C. (1989). The Dependence of Parametric Efficiency Tests on Measures of the Price of Capital and Capital Stock for Electric Utilities. Journal of Industrial Economics, 38(2), 199-213. http://dx.doi.org/10.2307/2098530

57) Färe, R., \& James, L. (1983). The Rate-of-Return Regulated Firm: Cost and Production Duality. Bell Journal of Economics, 14(2), 405-414. http://dx.doi.org/10.2307/3003642

58) Färe, R., \& James, L. (1986). Regulation, Scale and Productivity: A Comment. International Economic Review, 27(3), 777-781. http://dx.doi.org/10.2307/2526694

59) Gagnepain, P., \& Marc, I. (2002). Incentive Regulatory Policies: The Case of Public Transit Systems in France. RAND Journal of Economics, 33(4), 605-629. http://dx.doi.org/10.2307/3087477

60) Gal-Or, E., \& Michael, H. S. (1992). Regulatory Regimes in the Electric Power Industry: Implications for Capacity. Journal of Regulatory Economics, 4(3), 263-278. http://dx.doi.org/10.1007/BF00133623

61) Gilbert, R. J., \& David, M. N. (1994). The Dynamic Efficiency of Regulatory Constitutions. RAND Journal of Economics, 25(4), 538-554. http://dx.doi.org/10.2307/2555974

62) Goddard, F. O. (1971). On the Effectiveness of Regulation of Electric Utility Prices: Comment. Southern Economic Journal, 38(1), 125-126. http://dx.doi.org/10.2307/1056084

63) Gollop, F. M., \& Stephen, R. K. (1980). The Electric Power Industry: An Econometric Model of Intertemporal Behavior. Land Economics, 56(3), 299-314. http://dx.doi.org/10.2307/3146033

64) Gort, M., \& Richard, A. W. (1988). Foresight and Public Utility Regulation. Journal of Political Economy, 96(1), 177-188.

65) Granderson, G. (1999). The Impact of Regulation on Technical Change. Southern Economic Journal, 65(4), 807-822. http://dx.doi.org/10.2307/1061277

66) Granderson, G., \& Carl, L. (1996). The Impact of Regulation on Productivity Growth: An Application to the Transmission Sector of the Interstate Natural Gas Industry. Journal of Regulatory Economics, 10(3), 291-306. http://dx.doi.org/10.1007/BF00157674

67) Granderson, G., \& Knox, L. C. A. (1998). The Impact of Regulation on Input Substitution and Operating Cost. Southern Economic Journal, 65(1), 83-97. http://dx.doi.org/10.2307/1061353 
68) Greenwald, B. C., \& William, W. S. (1989). The Economics of Deregulation of Local Exchange Telecommunications. Journal of Regulatory Economics, 1(4), 319-339. http://dx.doi.org/10.1007/BF00139900

69) Guthrie, G. (2006). Regulating Infrastructure: The Impact on Risk and Investment. Journal of Economic Literature, 44(4), 925-972. http://dx.doi.org/10.1257/jel.44.4.925

70) Hayashi, P. M., \& John, M. T. (1976). Rate of Return Regulation and the Regulated Firm's Choice of Capital-Labor Ratio: Further Empirical Evidence on the Averch-Johnson Model. Southern Economic Journal, 42(3), 384-398. http://dx.doi.org/10.2307/1056617

71) Hayashi, P. M., Melanie, S., \& John, M. T. (1985). Pricing Efficiency under Rate-of-Return Regulation: Some Empirical Evidence for the Electric Utility Industry. Southern Economic Journal, 51(3), 776-792. http://dx.doi.org/10.2307/1057879

72) Herendeen, J. B. (1975). A Financial Model of the Regulated Firm and Implications of the Model for Determination of the Fair Rate of Return. Southern Economic Journal, 42(2), 279-284. http://dx.doi.org/10.2307/1056777

73) Hiebert, L. D. (2002). The Determinants of the Cost Efficiency of Electric Generating Plants: A Stochastic Frontier Approach. Southern Economic Journal, 68(4), 935-946. http://dx.doi.org/10.2307/1061501

74) Hirschey, M., \& James, L. P. (1983). Regulatory Influences on Managerial Incentives: Reply. Southern Economic Journal, 50(1), 267-269. http://dx.doi.org/10.2307/1058063

75) Hollas, D. R. (1989). Firm/Interruptible Gas Pricing Patterns in a Regulated Environment. Journal of Regulatory Economics, 1(1), 47-67. http://dx.doi.org/10.1007/BF00150297

76) Hollas, D. R., \& Stanley, R. S. (1988). An Examination of the Effect of Ownership Form on Price Efficiency: Proprietary, Cooperative and Municipal Electric Utilities. Southern Economic Journal, 55(2), 336-350. http://dx.doi.org/10.2307/1059107

77) Isaac, R. M. (1982). Fuel Cost Adjustment Mechanisms and the Regulated Utility Facing Uncertain Fuel Prices. Bell Journal of Economics, 13(1), 158-169. http://dx.doi.org/10.2307/3003437

78) Israilevich, P., \& Kim, J. K. (1987). A Test of Two Views of the Regulatory Mechanism: Averch-Johnson and Joskow. Library of the Federal Reserve Bank of Cleveland, Working Paper 8713. Retrieved from http://www.clevelandfed.org/research/workpaper/1987/wp8713.pdf

79) Joskow, P. L. (1972). The Determination of the Allowed Rate of Return in a Formal Regulatory Hearing. Bell Journal of Economics and Management Science, 3(2), 632-644. http://dx.doi.org/10.2307/3003042

80) Joskow, P. L. (1973). Cartels, Competition and Regulation in the Property-Liability Insurance Industry. Bell Journal of Economics and Management Science, 4(2), 375-427. http://dx.doi.org/10.2307/3003047

81) Joskow, P. L. (1973). Pricing Decisions of Regulated Firms: A Behavioral Approach. Bell Journal of Economics and Management Science, 4(1), 118-140. http://dx.doi.org/10.2307/3003142

82) Joskow, P. J. (1974). Inflation and Environmental Concern: Structural Change in the Process of Public Utility Price Regulation. Journal of Law and Economics, 17(2), 291-327. http://dx.doi.org/10.1086/466794

83) Kaestner, R., \& Brenda, K. (1990). The Effects of Regulation and Competition on the Price of AT\&T Intrastate Telephone Service. Journal of Regulatory Economics, 2(4), 363-377. http://dx.doi.org/10.1007/BF00134477

84) Milton, Z. K. (1969). Output of the Restrained Firm. American Economic Review, 59(4), 583-589.

85) Kahn, A. E. (1968). The Graduated Fair Return: Comment. American Economic Review, 58(1), 170-174.

86) Kennedy, T. E. (1977). The Regulated Firm with a Fixed Proportion Production Function. American Economic Review, 67(5), 968-971.

87) Klevorick, A. K. (1966). The Graduated Fair Return: A Regulatory Proposal. American Economic Review, 56(3), 477-484.

88) Klevorick, A. K. (1971). The Graduated Fair Return: A Further Comment. American Economic Review, 61(4), 727-729.

89) Klevorick, A. K. (1971). The 'Optimal' Fair Rate of Return. Bell Journal of Economics and Management Science, 2(1), 122-153. http://dx.doi.org/10.2307/3003164 
90) Klevorick, A. K. (1973). The Behavior of a Firm Subject to Stochastic Regulatory Review. Bell Journal of Economics and Management Science, 4(1), 57-88. http://dx.doi.org/10.2307/3003139

91) Knittel, C. R. (2002). Alternative Regulatory Methods and Firm Efficiency: Stochastic Frontier Evidence from the US Electric Industry. The Review of Economics and Statistics, 84(3), 530-540. http://dx.doi.org/10.1162/003465302320259529

92) Knittel, C. R. (2004). Regulatory Restructuring and Incumbent Price Dynamics: The Case of US Local Telephone Markets. Review of Economics and Statistics, 86(2), 614-625. http://dx.doi.org/10.1162/003465304323031157

93) Kolbe, L. A., \& Lynda, S. B. (1998). The Impact of Stranded-Cost Risk on Required Rates of Return for Electric Utilities: Theory and an Example. Journal of Regulatory Economics, 13(3), 255-275. http://dx.doi.org/10.1023/A:1008081104532

94) Kolpin, V. (2001). Regulation and Cost Inefficiency. Review of Industrial Organization, 18(2), 175-182. http://dx.doi.org/10.1023/A:1007823231402

95) Krouse, C. G., Kenneth, L. D., Christos, C., Tanja, D., Carter, J. M. R., \& Daniel, J. R. (1999). The Bell System Divestiture/Deregulation and the Efficiency of the Operating Companies. Journal of Law and Economics, 42(1), 61-97. http://dx.doi.org/10.1086/467418

96) Kwoka, J. E. Jr. (1993). Implementing Price Caps in Telecommunications. Journal of Policy Analysis and Management, 12(4), 726-752. http://dx.doi.org/10.2307/3325348

97) Laffont, J. J. (1994). The New Economics of Regulation Ten Years After. Econometrica, 62(3), 507-537. http://dx.doi.org/10.2307/2951658

98) Laffont, J. J., \& Jean, T. (1986). Using Cost Observation to Regulate Firms. Journal of Political Economy, 94(3), 614-641. http://dx.doi.org/10.1086/261392

99) Lasserre, P., \& Pierre, O. (1994). Factor Demands, Cost Functions, and Technology Measurements for Regulated Firms. Canadian Journal of Economics, 27(1), 218-242. http://dx.doi.org/10.2307/135812

100) Law, S. M. (1999). Holding the Line: The CRTC and the Pricing of Basic Canadian Cable Television Services. Canadian Journal of Economics, 32(2), 294-317.

101) Leland, H. E. (1974). Regulation of Natural Monopolies and the Fair Rate of Return. Bell Journal of Economics and Management Science, 5(1), 3-15. http://dx.doi.org/10.2307/3003089

102) Levy, B., \& Pablo, T. S. (1994). The Institutional Foundations of Regulatory Commitment: A Comparative Analysis of Telecommunications Regulation. Journal of Law, Economics, \& Organization, 10(2), 201-246.

103) Link, A. N. (1977). A Comment on the .Efficient Allocation of Resources in a Regulated and Unionized Monopoly. Southern Economic Journal, 44(2), 383-384. http://dx.doi.org/10.2307/1057595

104) Liston, C. (1993). Price-Cap versus Rate of Return Regulation. Journal of Regulatory Economics, 5(1), 25 48. http://dx.doi.org/10.1007/BF01066312

105) Lyon, T. P. (1995). Regulatory Hindsight Review and Innovation by Electric Utilities.. Journal of Regulatory Economics, 7(3), 233-254. http://dx.doi.org/10.1007/BF01067096

106) Lyon, T. P., \& John, W. M. (2005). Regulatory Opportunism and Investment Behavior: Evidence from the ILS. Electric Utility. RAND Journal of Economics, 36(3), 628-644.

107) MacAvoy, P. W., \& Roger, N. (1973). Relative Prices on Regulated Transactions of the Natural Gas Pipelines. Bell Journal of Economics and Management Science, 4(1), 212-234. http://dx.doi.org/10.2307/3003145

108) Majumdar, S. K. (1997). Incentive Regulation and Productive Efficiency in the U.S. Telecommunications Industry. Journal of Business, 70(4), 547-576. http://dx.doi.org/10.1086/209731

109) Marino, A. M. (1978). Peak Load Pricing under Regulatory Constraint: Two Remarks. Southern Economic Journal, 44(3), 606-615. http://dx.doi.org/10.2307/1057214

110) Marino, A. M. (1981). Optimal Departures from Marginal Cost Pricing: The Case of a Rate of Return Constraint. Southern Economic Journal, 48(1), 37-49. http://dx.doi.org/10.2307/1058594 
111) Mathios, A. D., \& Robert, P. R. (1989). The Impact of Alternative Forms of State Regulation of AT\&T on Direct-Dial, Long-Distance Telephone Rates. RAND Journal of Economics, 20(3), 437-453. http://dx.doi.org/10.2307/2555581

112) Mayo, J. W., \& Joseph, E. F. (1988). The Effects of Regulation on Research and Development: Theory and Evidence. Journal of Business, 61(3), 321-336. http://dx.doi.org/10.1086/296435

113) McNicol, D. L. (1973). The Comparative Statics Properties of the Theory of the Regulated Firm. Bell Journal of Economics and Management Science, 4(2), 428-453. http://dx.doi.org/10.2307/3003048

114) Meyer, R. A. (1975). Publicly Owned versus Privately Owned Utilities: A Policy Choice. Review of Economics and Statistics, 57(4), 391-399. http://dx.doi.org/10.2307/1935898

115) Meyer, R. A. (1976). Capital Structure and the Behavior of the Regulated Firm under Uncertainty. Southern Economic Journal, 42(4), 600-609. http://dx.doi.org/10.2307/1056252

116) Meyer, R. A. (1979). Regulated Monopoly under Uncertainty. Southern Economic Journal, 45(4), 11211129. http://dx.doi.org/10.2307/1056958

117) Miller, M. H., \& Franco, M. (1966). Some Estimates of the Cost of Capital to the Electric Utility Industry, 1954-1957. American Economic Review, 56(3), 333-391.

118) Miller, M. H., \& Franco, M. (1967). Some Estimates of the Cost of Capital to the Electric Utility Industry, 1954-1957: Reply. American Economic Review, 57(5), 1288-1300.

119) Mirakhor, A. (1976). Efficient Allocation of Resources in a Regulated and Unionized Monopoly. Southern Economic Journal, 42(4), 725-729. http://dx.doi.org/10.2307/1056267

120) Moore, T. (1970). The Effectiveness of Regulation of Electric Utility Prices.. Southern Economic Journal, 36(4), 365-375. http://dx.doi.org/10.2307/1056848

121) Moszer, I. M., \& Max, M. (1978). An Approach toward Unifying the Efficient and Fair Rates of Return. Southern Economic Journal, 45(2), 394-409. http://dx.doi.org/10.2307/1057670

122) Myers, S. C. (1972). The Application of Finance Theory to Public Utility Rate Cases. Bell Journal of Economics and Management Science, 3(1), 58-97. http://dx.doi.org/10.2307/3003071

123) Myers, S. C. (1973). A Simple Model of Firm Behavior under Regulation and Uncertainty. Bell Journal of Economics and Management Science, 4(1), 304-315. http://dx.doi.org/10.2307/3003152

124) Needy, C. W. (1976). Social Cost of the A-J-W Output Distortion. Southern Economic Journal, 42(3), 486489. http://dx.doi.org/10.2307/1056629

125) Needy, C. W. (1978). The Gold-Plating Controversy: A Reconciliation. Southern Economic Journal, 45(2), 576-582. http://dx.doi.org/10.2307/1057685

126) Nelson, R. A. (1983). Estimated Elasticities from Regulated and Unregulated Cost Functions. Economic Letters, 11(4), 311-318. http://dx.doi.org/10.1016/0165-1765(83)90022-8

127) Nelson, R. A. (1984). Regulation, Capital Vintage, and Technical Change in the Electric Utility Industry. Review of Economics and Statistics, 66(1), 59-69. http://dx.doi.org/10.2307/1924696

128) Nelson, R. A., \& Mark, E. W. (1983). Regulation, Scale Economies and Productivity in Steam-Electric Generation. International Economic Review, 24(1), 57-79. http://dx.doi.org/10.2307/2526115

129) Nelson, R. A., \& Mark, E. W. (1987). A Reply to Regulation, Scale and Productivity: A Comment. International Economic Review, 28(2), 535-539. http://dx.doi.org/10.2307/2526742

130) Nemoto, J., Yasuo, N., \& Seishi, M. (1993). Scale Economies and Over-Capitalization in Japanese Electric Utilities. International Economic Review, 34(2), 431-440. http://dx.doi.org/10.2307/2526923

131) Neuberg, L. G. (1977). Two Issues in the Municipal Ownership of Electric Power Distribution Systems. Bell Journal of Economics, 8(1), 303-323. http://dx.doi.org/10.2307/3003501

132) Niho, Y., \& Robert, A. M. (1983). Effects of Regulation and Capital Market Imperfections on the Dynamic Behavior of a Firm. Southern Economic Journal, 49(3), 625-636. http://dx.doi.org/10.2307/1058705

133) Nolan, J., Pamela, R., \& John, R. (2005). Small Market Air Service and Regional Policy. Journal of Transport Economics, 39(3), 363-378.

134) Nwaeze, E. T. (2000). Deregulation of the Electric Power Industry: The Earnings, Risk and Return Effects. Journal of Regulatory Economics, 17(1), 49-67. http://dx.doi.org/10.1023/A:1008101304713 
135) Okuguchi, K. (1975). The Implications of Regulation Induced Technical Change: Comment. Bell Journal of Economics, 6(2), 703-705. http://dx.doi.org/10.2307/3003253

136) Oum, T. H., \& Yimin, Z. (1995). Competition and Allocative Efficiency: The Case of the US Telephone Industry. Review of Economics and Statistics, 77(1), 82-96. http://dx.doi.org/10.2307/2109994

137) Oum, T. H., \& Anming, Z. (2004). Alternative Forms of Economic Regulation and Their Efficiency Implications for Airports. Journal of Transport Economics and Policy, 38(2), 217-246.

138) Pavia, T. M. (1995). Profit Maximizing Cost Allocation for Firms Using Cost-Based Pricing. Management Science, 41(6), 1060-1072. http://dx.doi.org/10.1287/mnsc.41.6.1060

139) Peles, Y. C., \& Jerome, L. S. (1976). The Effect of Rate of Return Regulation is Highly Sensitive to the Nature of the Uncertainty. American Economic Review, 66(3), 278-289.

140) Peles, Y. C., \& Jerome, L. S. (1979). On Regulation and Uncertainty: Reply. American Economic Review, 69(1), 195-199.

141) Peles, Y. C., \& Greg, W. (1996). Incentive Effects of Rate-of-Return Regulation: The Case of Hong Kong Electric Utilities. Journal of Regulatory Economics, 10(1), 99-112. http://dx.doi.org/10.1007/BF00133360

142) Perrakis, S. (1976). On the Regulated Price-Setting Monopoly Firm with a Random Demand Curve. American Economic Review, 66(3), 410-416.

143) Perrakis, S. (1976). Rate of Return Regulation of a Monopoly Firm with Random Demand. International Economic Review, 17(1), 149-162. http://dx.doi.org/10.2307/2526071

144) Perrakis, S., \& Izzet, S. (1972). Resource Allocation and Scale of Operations in a Monopoly Firm: A Dynamic Analysis. International Economic Review, 13(2), 399-407. http://dx.doi.org/10.2307/2526033

145) Pescatrice, D. R., \& John, M. T. III (1980). The Performance and Objective of Public and Private Utilities operating in the United States. Journal of Public Economics, 13(2), 259-276. http://dx.doi.org/10.1016/0047-2727(80)90016-X

146) Petersen, H. C. (1975). An Empirical Test of Regulatory Effects. Bell Journal of Economics, 6(1), 111-126. http://dx.doi.org/10.2307/3003217

147) Pint, E. M. (1992). Price-Cap versus Rate-of-Return Regulation in a Stochastic-Cost Model. The RAND Journal of Economics, 23(4), 564-578. http://dx.doi.org/10.2307/2555906

148) Pressman, I., \& Arthur, C. (1971). Behavior of the Firm under Regulatory Constraint: Note. American Economic Review, 61(1), 210-212.

149) Pressman, I., \& Arthur, C. (1973). Behavior of the Firm under Regulatory Constraint: Reply. American Economic Review, 63(1), 238.

150) Ranganathan, V. (2004). Electricity Act 2003: Moving to a Competitive Environment. Economic and Political Weekly, 39(20), 2001-2005.

151) Resende, M. (1999). Productivity Growth and Regulation in US Local Telephony. Information Economics and Policy, 11(1), 23-44. http://dx.doi.org/10.1016/S0167-6245(98)00020-1

152) Rothwell, G. S., \& Kelly, A. E. (1987). A Note on Allowed and Realized Rates of Return of the US Electric Utility Industry. Journal of Industrial Economics, 36(1), 105-110. http://dx.doi.org/10.2307/2098600

153) Saal, D. S., \& David, P. (2001). Productivity and Price Performance in the Privatized Water and Sewerage Companies of England and Wales. Journal of Regulatory Economics, 20(1), 61-90. http://dx.doi.org/10.1023/A:1011162214995

154) Sankar, U. (1972). Investment behavior in the U.S. Electric Utility Industry 1948-1968. Bell Journal of Economics and Management Science, 3(2), 645-664. http://dx.doi.org/10.2307/3003043

155) Sankar, U. (1977). Depreciation, Tax Policy and Firm Behavior under Regulatory Constraint. Southern Economic Journal, 44(1), 1-12. http://dx.doi.org/10.2307/1057294

156) Sappington, D. (1980). Strategic Firm Behavior under a Dynamic Regulatory Adjustment Process. Bell Journal of Economics, 11(1), 360-372. http://dx.doi.org/10.2307/3003421

157) Scheidell, J. M. (1976). The Relevance of Demand Elasticity for Rate-of-Return Regulation. Southern Economic Journal, 43(2), 1088-1095. http://dx.doi.org/10.2307/1057333 
158) Schmalensee, R. (1977). Valuing Changes in Regulated Firms' Input Prices. Southern Economic Journal, 43(3), 1346-1351. http://dx.doi.org/10.2307/1057792

159) Scott, F. A. (1983). A Note on Uncertain Input Prices, Profit Risk, and the Rate-of-Return Regulated Firm. Land Economics, 59(3), 337-341. http://dx.doi.org/10.2307/3145736

160) Shepherd, W. G. (1966). Regulatory Constraints and Public Utility Investment. Land Economics, 42(3), 348-354. http://dx.doi.org/10.2307/3145351

161) Sherman, R. (1977). Ex Ante Rates of Return for Regulated Utilities. Land Economics, 53(2), 172-184. http://dx.doi.org/10.2307/3145922

162) Sherman, R. (1977). Financial Aspects of Rate-of-Return Regulation. Southern Economic Journal, 44(2), 240-248. http://dx.doi.org/10.2307/1057577

163) Sherman, R. (1981). Pricing Inefficiency under Profit Regulation. Southern Economic Journal, 48(2), $475-$ 489. http://dx.doi.org/10.2307/1057946

164) Sherman, R. (2001). The Future of Market Regulation. Southern Economic Journal, 67(4), 782-800. http://dx.doi.org/10.2307/1061571

165) Sherman, R., \& Michael, V. (1982). Rate-Of-Return Regulation and Two-Part Tariffs. Quarterly Journal of Economics, 97(1), 27-42. http://dx.doi.org/10.2307/1882625

166) Sheshinksi, E. (1971). Welfare Aspects of a Regulatory Constraint: Note. American Economic Review, 61(1), 175-178.

167) Silva-Echenique, J. (1989). Quasi-Vertical Integration and Rate-Of-Return Regulation. Canadian Journal of Economics, 22(4), 852-866. http://dx.doi.org/10.2307/135502

168) Smith, V. K. (1974). The Implications of Regulation for Induced Technical Change. Bell Journal of Economics and Management Science, 5(2), 623-632. http://dx.doi.org/10.2307/3003124

169) Smith, V. K. (1975). The Implications of Regulation for Induced Technical Change: Reply. Bell Journal of Economics and Management Science, 6(2), 706-707. http://dx.doi.org/10.2307/3003254

170) Smith, V. K. (1981). Elasticities of Substitution for a Regulated Cost Function,. Economic Letters, 7(3), 215-219. http://dx.doi.org/10.1016/0165-1765(81)90054-9

171) Smithson, C. W. (1978). The Degree of Regulation and the Monopoly Firm: Further Empirical Evidence. Southern Economic Journal, 44(3), 568-580. http://dx.doi.org/10.2307/1057211

172) Smithson, C. W. \& Veendorp, E. C. H. (1982). The Optimum. Degree of Rate-of-Return Regulation: A Two Sector Analysis. Southern Economic Journal, 48(3), 733-744. http://dx.doi.org/10.2307/1058664

173) Spann, R. M. (1974). Rate of Return Regulation and Efficiency in Production: An Empirical Test of the Averch-Johnson Thesis. The Bell Journal of Economics and Management Science, 5(1), 38-52. http://dx.doi.org/10.2307/3003091

174) Spann, R. M., \& Edward, W. E. (1970). The Economics of Railroading: The Beginning of Cartelization and Regulation. Bell Journal of Economics and Management Science, 1(2), 227-244. http://dx.doi.org/10.2307/3003182

175) Spiegel, Y., \& Daniel, F. S. (1994). The Capital Structure of a Regulated Firm. RAND Journal of Economics, 25(3), 424-440. http://dx.doi.org/10.2307/2555770

176) Stein, J. L., \& George, H. B. (1972). Behavior of the Firm under Regulatory Constraint. American Economic Review, 62(5), 964-970.

177) Stonebraker, R. J. (1972). A Geometric Treatment of Averch-Johnson's Behavior of the Firm Model: Comment. American Economic Review, 62(1/2), 140-141.

178) Strimling, D. V., \& Abbas, M. (1974). A Note on the Averch-Johnson Effect Controversy. Southern Economic Journal, 41(1), 149-151. http://dx.doi.org/10.2307/1056108

179) Taggart, R. A. Jr. (1981). Rate-of-Return Regulation and Utility Capital Structure Decision. Journal of Finance, 36(2), 383-393.

180) Takayama, A. (1969). Behavior of the Firm under Regulatory Constraint. American Economic Review, 59(3), 255-260. 
181) Thomadakis, S. B. (1982). Price Regulation under Uncertainty in an Asymmetric Decision Environment. Quarterly Journal of Economics, 97(4), 689-698. http://dx.doi.org/10.2307/1885106

182) Turnbull, G. K. (1984). Uncertain Input Prices, Profit Risk, and the Rate-of-Return Regulated Firm: Comment. Land Economics, 60(4), 408-410. http://dx.doi.org/10.2307/3145718

183) Turnbull, G. K. (1986). Theory of the Firm under the Threat of Input Supply Interruption. Southern Economic Journal, 52(3), 807-817. http://dx.doi.org/10.2307/1059276

184) Vogelsang, I., \& Jorg, F. (1979). A Regulatory Adjustment Process for Optimal Pricing by Multiproduct Monopoly Firms. Bell Journal of Economics, 10(1), 157-171. http://dx.doi.org/10.2307/3003324

185) Waverman, L. (1975). Peak-Load Pricing under Regulatory Constraint: A Proof of Inefficiency. Journal of Political Economy, 83(3), 645-654. http://dx.doi.org/10.1086/260345

186) Wellisz, S. H. (1963). Regulation of Natural Gas Pipeline Companies: An Economic Analysis. Journal of Political Economy, 71(1), 30-43. http://dx.doi.org/10.1086/258732

187) Wenders, J. T. (1976). Peak Load Pricing in the Electric Utility Industry. Bell Journal of Economics, 7(1), 232-241. http://dx.doi.org/10.2307/3003198

188) Westfield, F. (1965). Regulation and Conspiracy. American Economic Review, 55(3), 424-443.

189) Westfield, F. (1971). Methodology of Evaluation of Economic Regulation. American Economic Review, 61(2), 211-217.

190) Wills, H. R. (1982). The Simple Economics of Bank Regulation. Economica New Series, 49(195), 249-259. http://dx.doi.org/10.2307/2553625

191) Zajac, E. E. (1970). A Geometric Treatment of Averch-Johnson's Behavior of the Firm Model. American Economic Review, 60(1), 117-125.

192) Zhang, F. (2007). Does Electricity Restructuring Work? Evidence from the US Nuclear Energy Industry. Journal of Industrial Economics, 55(3), 397-418. http://dx.doi.org/10.1111/j.1467-6451.2007.00317.x

\section{Copyrights}

Copyright for this article is retained by the author(s), with first publication rights granted to the journal.

This is an open-access article distributed under the terms and conditions of the Creative Commons Attribution license (http://creativecommons.org/licenses/by/3.0/). 